\title{
Lifetime Employment in Japan: Concepts and Measurements
}

SSE/EFI Working Paper Series in Economics and Finance No 624.

\section{Hiroshi Ono}

\section{Stockholm School of Economics}

March 2007

\begin{abstract}
This paper poses three fundamental questions about lifetime employment in Japan: How big is it? How unique is it? And, how is it changing? I examine different concepts and methods for estimating lifetime employment and conclude that it covers roughly 20 percent of the Japanese labor force. Job mobility remains considerably lower in Japan than in other economies (particularly the U.S.). Evidence regarding changes in lifetime employment is mixed. The share of workers in the core, an ex-ante measure of lifetime employment, is declining. But the probability of job separations has remained stable for those who are already in the system. I also find evidence that the incentives among workers, managers and executives are aligned to preserve the lifetime employment system.
\end{abstract}

Keywords: Lifetime employment; job mobility JEL codes: J24; J42; J62

* Paper presented at the annual meeting of the Population Association of America, New York, March 2007. Direct all correspondence to Hiroshi Ono, Stockholm School of Economics, P.O. Box 6501, 11383 Stockholm, Sweden <hiroshi.ono@hhs.se>. 


\section{Introduction}

This paper poses three fundamental questions about lifetime employment in Japan: How big is it? How unique is it? And, how is it changing? The first question concerns the lifetime employment rate, which refers to the proportion of the labor force that is covered by lifetime employment. Despite significant advances and contributions in all possible areas of lifetime employment, hard data regarding its actual size is rarely reported. The question how big is lifetime employment? - is perhaps one of the most frequently posed questions in empirical research, and yet few researchers have seriously undertaken the effort to estimate its size with precision. Informed scholars are aware that its actual coverage is limited to a minority share of the Japanese labor force. As Ohtake (2001) explains, "if one assumes that all employees of Japanese corporations are hired under the lifetime employment system, then such a person has seriously misconstrued the Japanese employment system" (p.29). Some point to 30 percent or one-third (Form 1979; Hashimoto and Raisian 1985; Schregle 1993), but one-third of what? What is the denominator, and what is the numerator? The confusion stems from the lack of consensus concerning the definition of lifetime employment, of which discussions become quickly confounded in conflicting or overlapping concepts.

The implicit nature of lifetime employment is the root of the problem in measurement, as there is no unified survey method to estimate its size. Lifetime employment is not a contractual state (Itoh 1991). The employment contract includes no explicit clause regarding this policy, and employers are under no obligation to guarantee employment. Lifetime employment is thus better understood as a long-term commitment between workers and employers rather than a permanent employment contract. As such, a worker survey cannot ask the question, "Are you covered by lifetime employment?" Likewise, an employer survey cannot ask the question, "What proportion of your workforce is covered by lifetime 
employment?" And even if such questions could be posed, there would be considerable discretion in their interpretations which would result in severe measurement bias. ${ }^{1}$

An accurate assessment of lifetime employment invariably requires the time dimension. Information concerning past job histories are required to examine patterns of labor market mobility. But such microdata are not readily available in Japan. Large scale employment surveys conducted by the central government ministries are not available as microdata, but only as published statistics. Longitudinal data, by either government or private organizations, are non-existent. ${ }^{2}$ As such, measuring lifetime employment in Japan requires simplifications and approximations from which we may deduce its size and speculate its direction of change. I review the existing literature and outline the various methods used to estimate the size of lifetime employment, and present the latest available measures.

While estimations of lifetime employment provide a better understanding of the "facts," their utility will be limited unless we know how the facts compare to other economies. The second question therefore assesses the uniqueness of Japan's long-term employment in an international context. Long-term employment is observed in other industrialized economies, so why the exclusive focus on Japan? Is there a pattern that is unique to Japan? One of the problems underlying comparative research on employment durations is the lack of comparable data. Consequently, much of the existing research relies on U.S.-Japan comparisons. However, these two countries represent two extremes, so the findings

\footnotetext{
${ }^{1}$ Some researchers claim that a precise measurement of lifetime employment is not possible because there are too many gray areas regarding its coverage and application (Abegglen and Stalk 1985; Schregle 1979). Cole (1979) explains that workers will only be confused when they are asked whether they are covered by lifetime employment. Some employer surveys may directly pose the question about lifetime employment coverage, but this method is questionable. For example, the following is an excerpt from an employer survey administered by the Center for Public Resources Development (2003): "We assume that all workers employed by your organization are covered by lifetime employment. If lifetime employment only applies to your regular workers, then please indicate the proportion covered by lifetime employment to be the proportion of regular workers employed by your organization. If lifetime employment does not necessarily apply to your regular workers, then please provide us with your own definition of lifetime employment, and the proportion covered in your organization under this definition."

2 Panel data from the Institute for Research on Household Economics is available on request. But the first wave was conducted in 1993, and the sample $(\mathrm{N}=1,500)$ consists only of women.
} 
unanimously show support for long-term employment in Japan when compared to the U.S. My comparative analysis will likewise be constrained by data, but I nevertheless attempt to evaluate the uniqueness of lifetime employment in Japan relative to the U.S. and other countries.

The third question here looks at changes in the lifetime employment practice over time. This area has received the most attention, perhaps more so in policy and the media than in the academic community. The debate over the demise of lifetime employment is hardly new. It is a recurring theme which has evolved over the postwar period in response to fluctuations in the business cycle, not only during the slump years but also during the growth years (Moriguchi and Ono, forthcoming; Ono 1997). Most recently, the debate focuses on the lost decade of the 1990s and its impact on the lifetime employment system. If we take the journalistic coverage at face value, then all signs point to the end of lifetime employment in Japan. But on what basis can we claim its demise? Changes in lifetime employment really depend on how one defines it, which puts more emphasis on my first question. Indeed, for every scholarly article written about the demise of lifetime employment, there is another which indicates its stability and resilience.

Paralleling this debate in Japan, a panel of experts examined trends in job stability and job security in the U.S., primarily in response to the wake of journalistic and anecdotal accounts suggesting the end of lifetime jobs in the U.S. in the 1990s. Their collective efforts (published in the special issue, "Changes in Job Stability and Job Security," Journal of Labor Economics [1999], and also in edited volume by Neumark 2000) found some evidence of declining job stability in the 1990s, but they conclude that these changes were not overwhelmingly large, and have not persisted long enough to constitute a widespread shift in the U.S. labor market. 
The absence of large, high-quality datasets, such as are available in the U.S., make it difficult to carry out a comprehensive and systematic evaluation of the state of employment stability in Japan. However, we can track and monitor the movements, as long as we define the concepts and measurements of lifetime employment with consistency and clarity. By some accounts, my analysis may lead to seemingly conflicting findings. The final section of the paper attempts to make sense of these in a consistent framework.

Owing to the keen interest in the academic community, there is now a rich and extensive collection of theoretical and empirical literature covering all possible aspects of lifetime employment in Japan, but very little discussing its actual size. Instead of adding to this existing literature, my main contribution is to provide an accurate measurement of the size of lifetime employment.

I also contribute to the literature by highlighting gender differences in lifetime employment. It is often argued that lifetime employment is gender biased by design (Ono, forthcoming). The system favors men who are able to make long-term commitments, but disfavors women who are not in a position to do so because they are expected take on family obligations. However, it is hasty to assume that women are automatically excluded from coverage, which is more often than not the underlying assumption in much of the earlier studies. I examine the data for both men and women, and assess the extent of gender asymmetries in the lifetime employment system.

\section{Concepts and measurements of lifetime employment: Review of the literature}

Previous literature on lifetime employment points to two broad categories of measurement and its applications - the labor market segmentation (or ex-ante) method and the ex-post method. Their main contributions are outlined in Table 1 in chronological order of their citations. 


\section{TABLE 1 ABOUT HERE}

\section{Labor market segmentation (ex-ante) method}

The labor market segmentation method partitions the labor market into specified segments, and presupposes that certain employers are in the position to offer lifetime employment, while others are not. Workers who are covered by lifetime employment constitute the "core" workforce, to distinguish them from the "periphery" workforce. The lifetime employment rate is thus equal to the size of the core workforce divided by the total size of the labor force.

The segmentation method is a static, ex-ante view of the labor market which rests on some rather strong assumptions. It implicitly assumes that employers offer lifetime employment as a benefit by protecting their core workers from fluctuations in labor demand and the ensuing threat of dismissals. The likelihood of offering lifetime protection to their employees is directly related to the size of the employer. The exclusion of small and medium enterprises from the estimations presupposes that SME's are not in the position to offer these benefits.

The segmentation method is rooted in the persistence of the dual labor market structure in Japan where firm size is the line that separates the primary from the secondary labor market (Ishikawa and Dejima 1994). ${ }^{3}$ Comparative studies have found that labor market demarcation in Japan is more pronounced along lines of firm size rather than along different product markets and industries (Bronfenbrenner and Yasuba 1987; Rebick 1993; Tachibanaki and Ohta 1994). Larger firms offer greater benefits - both monetary and non-

\footnotetext{
${ }^{3}$ The dual labor market structure overlaps with the concept of the internal labor market. For example, Koike (1977) writes that the long-term employment relationship found in large firms in Japan is comparable to the conditions of internal labor markets found elsewhere. Ariga et al (2000) argues that firm size is a useful but an incomplete measure of an internal labor market. The latter is multi-dimensional and determined by the distribution of firm size, industry, and occupations.
} 
monetary - and the magnitude of this firm-size effect in Japan has been found to be stronger than those reported in other countries. ${ }^{4}$

Previous research using this method has evolved over time by imposing additional conditions to the definitions of core workers established by their predecessors (see Table 1). Taira (1962) suggests that lifetime employment applies to regular employees in unionized establishments of more than 500 persons. Dore (1973) adds to Taira's definition by including government sector employees. Cole (1979), in response to Dore, explains that women are rarely covered by lifetime employment, and revises Dore's estimates downward. ${ }^{5}$ Abegglen and Stalk (1985) argue that lifetime employment is not coterminous with unionization. The Ministry of Labor (1993) sets forth their definition by delineating the lifetime workforce as male regular workers in government, and in the non-agricultural sector in firms $\geq 500$.

The utility of the labor market segmentation method is utmost in its convenience and ease of calculation. Tabulations of the labor force by establishment size and other attributes are widely available from various government statistics. Estimating the lifetime employment rate thus does not require access to microdata; it is simply an exercise in counting the labor force. The method is also useful because it allows consistent comparisons over time.

But there are obvious drawbacks to the segmentation method. First, it is a static, snapshot view of the labor market which ignores the time dimension of lifetime employment. To assume that all employees are hired for life in large establishments, but none are among SME's is highly problematic. Second, the dividing line that separates large establishments from SME's is arbitrary. Using establishment size of 500 as the dividing line is a matter of convention, and there is no theoretical or empirical justification for its application. Third, it rests crucially on the assumption of the dual labor market structure in Japan. Applying this

\footnotetext{
${ }^{4}$ For example, Rebick (1993) finds that the difference in logged average hourly earnings between large (more than 1000) and small firms (less than 100) in Japan was .54 compared to .28 in the U.S.

${ }^{5}$ This point is also emphasized by Form (1979) who explains Japan's dual labor market structure as follows: "One market offers lifetime security to a minority of men working in large corporations; but the major free market exposes women, the poorly educated, and the aged to the vicissitudes of freedom" (p.13).
} 
method in an international context is impractical, because segmentation by firm size is less pronounced in other countries. And fourth, the automatic exclusion of female workers from the lifetime employment system is outdated. As it stands, the segmentation method cannot estimate the share of women employed under lifetime employment. Women may have been systematically excluded from lifetime employment in the past, but they have made significant advances. Applying this rule to the realities of current labor market conditions is thus questionable.

\section{Ex-post method}

The ex-post method views lifetime employment as a behavioral outcome of surviving job separations at specified durations of employment. It is closer to the intuition of lifetime employment as we know it. In its most basic form, lifetime employment refers to the practice whereby a worker remains with the same employer until the age of retirement. The list of citations provided in Table 1 is by no means exhaustive, but this is not a major setback because they are generally variations on the same theme. Abegglen (1958)'s definition emphasizes the lifetime commitment aspect of employment relationships using the analogy of membership to family and other intimate relationships. This behavioral definition is modified by adding certain conditions which limit its coverage. Ohkochi (1972) sets forth the condition of "infancy" (kogai). In this context, new school graduates are considered to be infants, and the firm takes on the parental role of raising their workers as if they were their own children. He further explains that lifetime employment does not extend beyond mandatory retirement age. Cole (1979) and Koike (1980) emphasize that employees must be hired right after school graduation. These two conditions are echoed by Ono (1997) who also adds that the coverage includes workers regardless of employment status or occupation.

To summarize, lifetime employment must fulfill the following two conditions. 
Condition 1 "infancy": Immediate employment following school graduation (at time $t_{g}$ ).

Condition 2 "long-term employment": Continuous "long-term" employment with the same firm from $t_{0}$ to $t$.

where the time units $(t)$ can be expressed in terms of age, calendar year, or in relative terms.

Lifetime employment in its purest form must fulfill both conditions simultaneously where $t_{g}=t_{0}$ and $t=$ time of mandatory retirement. Ono (1989) emphasizes that the condition of infancy is the crucial feature which distinguishes lifetime employment from long-term employment. Long-lasting employment relationships may be witnessed in other economies, but one which emphasizes infancy may be unique to Japan.

If we set $t_{0}=0$ in condition 2 , then $t$ is simply equal to tenure, or the duration of employment with the same employer. If total years of work experience is $x$, then we obtain the internal experience rate expressed as:

$$
\begin{aligned}
\text { Internal experience rate } & =\frac{\text { Years of internal experience }}{\text { Years of internal experience }+ \text { Years of external experience }} \\
& =\frac{\text { Tenure }(t)}{\text { Total years of work experience }(x)}
\end{aligned}
$$

Pure lifetime employment requires that the internal experience rate is equal to 100 percent, which requires that $t=x$, or years of external experience $=0$; at any given stage in the career, the lifetime worker has never been employed by a firm other than the current one. This condition is known as "nativity" (or haenuki). Taken together with condition 1, native workers are "pure" in the sense that their careers have never been adulterated by the work cultures of other employers. ${ }^{6}$ Any gaps between school graduation and first employment are regarded as impurities. Native workers and lifetime workers are similar expressions, but lifetime workers in the strict sense have survived separations until $t=$ mandatory retirement age, while native workers may experience separations at any given $t$. This is a subtle

\footnotetext{
${ }^{6}$ Ono (1997) sometimes uses the expression "virgin workers" in reference to native workers.
} 
distinction which does not affect the estimations since tracking workers until retirement age is impossible in practice due to data limitations. Native workers are taken to be synonymous with lifetime workers hereafter.

I have thus far outlined the basic premise of lifetime employment which enables us to estimate the size of the lifetime workforce with reasonable certainty. But the question of how to estimate the lifetime employment rate remains. The short answer is that it depends on the assumptions, and more practically, on the data available. A number of simplifications are necessary that conventionally involve some approximations of $t_{g}, t_{0}$ and mandatory retirement age. For example, Hall (1982) considers employment durations lasting longer than twenty years (and those that are expected to last more than twenty years) as lifetime jobs in the U.S. labor force. Variations in the measurements of the lifetime employment rate are discussed in Section 3.

\section{Mobility measures}

In addition to the two broad concepts of lifetime employment, there are various measures of labor mobility which are frequently used to assess changes in job stability. The mobility measures I review include tenure distribution, retention rates, number of jobs held, separation rates, and accession rates. The list is not exhaustive, but sufficient for the purpose of gaining a multi-dimensional perspective on labor market mobility.

The advantage of mobility measures is that (with some exceptions) the data are collected and tabulated by the government ministries. This allows us to make reliable and consistent comparisons over time, and in some cases across countries. Another advantage is that (because of the limited access to microdata in Japan) the majority of previous studies examine changes in lifetime employment based on these mobility measures. Their main findings and contributions are discussed in the following section. 


\section{Measuring lifetime employment}

(1) Core workforce

The labor market segmentation method presupposes that establishment size is one crude measure which distinguishes whether an employer is in a position to offer lifetime employment or not. Although the dividing line is debatable, I estimate the core workforce following the Ministry of Labor (1993)'s classification. The core workforce and its share of the labor force are thus:

$$
\begin{aligned}
& \text { Core workforce } \quad=\begin{array}{c}
\text { Male regular employees in establishments greater than } 500 \text { persons } \\
+ \text { Male regular employees in the government sector }
\end{array} \\
& \text { Core workforce }(\% \text { share })=\frac{\text { Core workforce }}{\text { Employed persons }}
\end{aligned}
$$

Following the ILO classification, employed persons are defined as persons in the nonagricultural sector above the age of 15 who worked for at least one hour during the survey period. Regular employees exclude nonstandard workers which consist of part-time, temporary and contract workers. Executives and the self-employed are excluded from the sample.

Under this method, the core workforce in 2003 is found to be 19.2 percent. According to the Ministry of Labor estimates, this proportion declined from 23.4 percent in 1985 to 21.6 percent in 1991 . Based on these estimates, they suggest that the proportion of workers who are believed to be covered by the lifetime employment system has declined over time (Ministry of Labor 1993). My estimation for the year 2003 thus indicates stronger support to this effect.

However, as previously discussed, there are numerous drawbacks to the segmentation method. The lifetime employment rate estimated under this method should 
therefore not be taken at face value. Interpretations should be limited to changes in the relative size of the lifetime workforce, and not its absolute size. The Ministry of Labor offers their own explanation as follows:

This is not to argue that the lifetime employment system does not apply to women and workers in small to medium size firms. However, the overall trend suggests that the gradual increase in the number of workers who are believed to be not covered by the lifetime employment system resulted in the reduction in the proportion of workers who are believed to be covered by it. (Ministry of Labor 1993, p.248)

(2) Standard employment

The definition of the core workforce presupposes that nonstandard workers, regardless of how long their employment duration or commitment to their employers, are excluded from the lifetime employment system. Tracking standard employment is therefore one method to monitor overall trends in lifetime employment.

The proportion of standard workers declined from 80.2 percent in 1991 to 69.6 percent in 2003 (Figure 1). In absolute terms, the number of standard workers shrank by 2 million and the number of nonstandard workers expanded by 6.1 million. The reduction of standard workers in both relative and absolute terms suggests that the size of the labor force where lifetime employment is believed to apply has contracted over time. ${ }^{7}$

Figure 1 also reveals a sizeable gender difference in nonstandard employment. In 2003, the proportion of men in standard employment was 84.5 percent; among women it was 49.5 percent. In 1991, these numbers were 91.5 percent and 62.8 percent, respectively. The reduction in standard employment therefore disproportionately affected women relative to men.

The decline of standard employment in Japan is accelerating at a rate faster than the OECD average. The share of part-time work in total employment in Japan was 24.9 percent

\footnotetext{
${ }^{7}$ The proportion of workers switching from full-time to part-time employment also expanded, from 6.3 percent in 1991 to 9.5 percent in 2002 (MHLW statistics).
} 
in 2001, the third highest country among the OECD member states (OECD 2003). Between 1991 and 2001, the proportion of full-time employment to total employment declined by an average of -.4 percent per annum while the corresponding proportion for part-time employment grew by .5 percent per annum. This pattern - the contraction of full-time employment and expansion of part-time employment - was observed in only 4 out of the 30 member states.

(3) Lifetime (or "native") workers

The Wage Census includes a category of workers called "standard workers" (hyoujun rodosha) which refers to those who were employed immediately after school graduation and have been continuously employed by the same employer at the time of the survey. This definition therefore fulfills the conditions of infancy and nativity under lifetime employment. To avoid confusion with workers hired in standard employment, I refer to these workers as lifetime workers hereafter.

The lifetime employment rate in age category $i$ at time $t$ is estimated as the proportion of lifetime workers to the total number of workers in age category $i$ :

$$
\begin{aligned}
L E R \text { in age category } i & =\frac{L_{i}}{N_{i}} \\
N_{i} & =N_{i}^{*}+A_{i}+B_{i}
\end{aligned}
$$

$L_{i}=$ Lifetime workers in age category $i$ at time $t$ who started working at $t_{0}$

$N_{i}=$ All workers in age category $i$ at time $t$

$N_{i}{ }^{*}=$ Workers in age category $i$ at time $t$ who started working at $t_{0}$

$A_{i}=$ Workers in age category $i$ at time $t$ who started working after $t_{0}$

$B_{i}=$ Workers in age category $i$ at time $t$ who left but returned to the labor force between $t_{0}$ and $t$

Because the Wage Census does not include retrospective employment data, only $N_{i}$ is available, and $N_{i}{ }^{*}, A_{i}$ and $B_{i}$ are not directly recorded. Restricting the denominator to $N_{i}{ }^{*}$ would yield an alternative measure of lifetime employment where $L_{i}=N_{i}{ }^{*}$ at $t_{0}$, and both $L_{i}$ 
and $N_{i}{ }^{*}$ are monotonically decreasing over $i$. This is the case of survival analysis which I take up in the following section.

The inclusion of $A_{i}$ and $B_{i}$ implies that $N_{i}$ is not necessarily a monotonically decreasing function of $i$. The estimation results require some caution, mainly that $L E R$ will always decline for older workers even if $L_{i}$ remains the same. Consider the case of women. As characterized by the so-called M-curve of labor force participation rates over the lifecycle, Japanese women enter the labor force in comparable numbers as men, but a sizeable number will exit the labor force upon marriage and childbearing, and return to the labor force at later stages. In the case of age $35<i<$ age 50 , for example, $N_{i}<N_{i+1}$ so $L E R_{i+1}<L E R_{i}$ always, even if $L_{i}=L_{i+1}$.

Table 2 presents the lifetime employment rate estimated from the Wage Census for various years between 1980 to 2000 . The data for 1980 are reprinted from Tachibanaki (1984). His estimations are based on the 1980 Wage Census, so the data are directly comparable to my estimations for the time period 1984 to 2000 . I set the upper age limit to 54 (as did Tachibanaki), and exclude workers 55 and over as their lifetime employment rate may be obscured by the higher propensity of workers to switch jobs after retirement age. LER for the age group 50 to 54 is roughly equivalent to the lifetime employment rate that fulfills both conditions 1 and 2. These workers have been continuously employed since school graduation, and are close to reaching the retirement age.

In general, the proportion of lifetime workers in the labor force increased across all age categories during the period 1980 to 2000 . Men are significantly more likely to be lifetime workers than are women. LER declines among older workers, but the rate of decline is faster for women. In 2000, the proportion of lifetime workers remaining in the labor force at age 50 to 54 was 23 percent for men versus only 4 percent for women. 
I next restrict the sample to workers who are close to reaching retirement. The mean LER for the age group 50 to 54 (men and women combined) increased from 7.4 to 17.9 percent. Results for men only in this age group clearly show that education and firm size are both positively correlated with the lifetime employment rate. In the case of university graduates in firm size $\geq 1000$, presumably the group of workers who are most likely to be covered by lifetime employment, over half are lifetime workers.

\section{TABLE 2 ABOUT HERE}

Chuma (1997) estimates the lifetime employment rate using the Wage Census microdata for the time period 1980 to 1994 . His definition of lifetime workers allows for the possibility that some workers may have spent an additional year either getting into or out of university. In our terminology, condition $t_{g}=t_{0}$ required under pure lifetime employment is relaxed to be $t_{0}-t_{g} \leq 1$. This distinction obviously broadens the scope of lifetime workers, but the overall trend in the expansion of the lifetime workforce over time (1980 to 1994) remains the same, from 38 to 53 percent for male university graduates, and 17 to 33 percent for male high school graduates. He concludes that "with regards to male workers in mid- to late-career, lifetime employment has not declined since the mid-1980s, but rather shows sign of covering a wider proportion of workers" (Chuma 1997, p.58).

(4) Lifetime employment in management and executive positions

Internal promotion is one of the distinguishing features of the Japanese employment system. The practice refers to the promotion (or upgrading) of incumbents from lower ranks within the organization. The candidates for internal promotion therefore include both native and non-native workers. The questions that motivate our research are whether nativity 
improves promotion rates, and if so, how has this practice changed over time? Previous research has consistently shown that nativity is positively correlated with promotion. For example, Ariga et al (2000) use the distinction regulars versus irregulars (comparable to natives versus non-natives), and finds that the regulars are significantly more likely to be internally promoted than are irregulars. I discuss further evidence below.

Comparative studies have found that nativity is indeed crucial in promotion decisions in the Japanese firm. Ono and Shiraishi (1993) for example, report findings from a survey of managers conducted in U.S. firms and Japanese firms based in the U.S. which asked the question: "Is nativity important in the promotion of workers into management positions?" In the U.S. firms, 65 percent of upper management and 57 percent of middle management responded "not important at all." In the Japanese firms, this response rate was less than 2 percent for both management levels.

One way to examine the persistence of nativity in internal promotions is to look at the lifetime employment rate at different ranks of the organization. In this tradition, Ono (1997) uses microdata from the Wage Census and estimates the lifetime employment rate for male managers using a method comparable to the one discussed previously $(L E R)$. He finds that the lifetime employment rate increased across all levels of management (from low-level management to division chief) during the years 1980 to 1990 . Moreover, lifetime (or native) workers tend to be younger than "non-native" workers within the same level of management, implying that the former have faster promotion rates. Ono (1997) further extends his analysis to the sample of upper level managers and executives using data from the Diamond Directory of Executives for the years 1975 and 1984. He shows that the lifetime employment rate 
increased during these years, from 25 to 37 percent among executives, and from 52 to 69 percent among non-executives (above section chief but below managing directors). ${ }^{8}$

In a similar vein, I analyze the lifetime employment rate among executives using microdata from 1993 and 1997. The 1993 data come from the Survey of Company Executives' Careers conducted by the Japan Trade Union Confederation. The sample size is 2,246 with mean age of 57.7, and consists of executives among the listed companies plus unlisted insurance companies which were randomly sampled from the Toyokeizai Directory of Executives $1994 .^{9}$ Executives include chairman, vice-chairman, president, and managing directors. ${ }^{10}$ The 1997 data come from the Diamond Directory of Executives 1998. The sample consists of only presidents among the listed companies, with sample size 2,231 and mean age of 62.2. In Table 3, the column "internal experience" is the ratio of tenure divided by total years of work experience, expressed in percentages. For lifetime workers, this ratio equals 100 percent. Internal experience greater than 50 percent indicates that the executive has more internal experience than external experience. ${ }^{11}$

The results for 1993 indicate that internal promotion remains the norm for executives in Japanese corporations. The majority (63 percent) of executives are lifetime workers, with mean tenure of 27 years, and mean internal experience of 80 percent. In a more recent study,

\footnotetext{
${ }^{8}$ Ono (1997)'s estimation results are reported by industry for the 22 industries covered in the survey. I estimated the weighted average by using the frequency distributions of workers by industry reported in the Enterprise Census for the years 1975 and 1984.

${ }^{9}$ In the 1993 data, 8,000 executives were randomly selected from the Toyokeizai Directory of Executives 1994 consisting of 40,800 executives representing 2,157 companies. The sample is therefore the result of cluster sampling where the sampling unit is the company. This leaves the possibility of homogeneity among observations obtained within the same company. However, using the available information on industry, firm size and capital, I identified 1,884 unique companies in the data. The maximum number of observations from any one company was five. I therefore assume that homogeneity within sampling units did not significantly bias the results. It should further be noted that there is only one president per company. The estimation results for presidents in Table 3 are therefore free of any bias that may be associated with cluster sampling.

${ }^{10}$ Following Wailerdsak and Suehiro (2004), I exclude auditors because they do not have direct input in management.

${ }^{11}$ The current sample excludes executives who may have graduated from school after joining the firm, such as those who may have completed their education through evening school. For these workers, $t_{g}>t_{0}$ which would violate the condition of "pure" lifetime employment. I estimated the lifetime employment rate for the sample that includes these executives. The results were almost identical (and are not reported here) suggesting that the lifetime employment rate is not sensitive to the exclusion of evening school graduates. See Ono (1997) for a similar estimation of lifetime employment that separates workers into the sample of $t_{g}=t_{0}$ and $t_{g} \geq t_{0}$.
} 
Wailerdsak and Suehiro (2004) use the same database (Toyokeizai Directory of Executives) and estimate the proportion of lifetime executives to be 71 percent in 2001 . The lifetime employment rate among executives therefore increased from 1993 to 2001.

The results also vary across ranks. On average, presidents have the shortest tenure, smallest percentage of lifetime workers, and smallest ratio of internal experience. Looking only at the group of presidents, vice-presidents and managing directors, we observe a general pattern where the proportion of lifetime workers and the ratio of internal experience decline in the opposite direction from rank. Hence, the likelihood of internal promotion is smaller at the higher ranks of executive positions. ${ }^{12}$

Breaking down the sample by firm size categories reveals the significance of firm size effects on promotion. Internal promotion is more common among the larger firms (here defined as firm size $\geq 1,000$ ); two-thirds of all executives are lifetime workers, with internal experience ratio greater than 80 percent. The firm size effect is also significant among the sample of presidents only. These results may partly reflect the employment practice where top executives are transferred from large firms to smaller firms (Noda 1995).

\section{TABLE 3 ABOUT HERE}

The results for 1997 for the sample of presidents show a modest increase in the proportion of lifetime workers, mean tenure, and mean internal experience. ${ }^{13}$ A breakdown by firm size categories shows an identical pattern to the one found in 1993, where lifetime employment rates are considerably higher among larger firms.

\footnotetext{
${ }^{12}$ Ito and Teruyama (1995) examine the tenure distribution among executives using the same dataset. They explain that the short tenure of presidents is attributable to the higher likelihood of externally hired executives that are appointed to presidents. ${ }^{13}$ Increase in mean tenure may be partly attributable to the rise in the mean age of presidents which increased
from 60.9 to 62.2 over these years.
} 
In my final analysis, I examine the sample of executives in the top 100 firms as measured by their firm size and capital. These measures allow us to make a rough comparison of the Japan data to empirical estimations obtained from Cappelli and Hamori (2004) in the U.S. Their sample consists of top executives among the Fortune 100 companies for the years 1980 and 2001. While the Fortune 100 companies are selected on the basis of revenue in the previous year, I am unable to do this because revenue data are not included in my dataset. As a rough approximation, I selected the top 100 companies by rank order of their firm size and capital. ${ }^{14}$ In the 1993 data, firm size was recorded in six categories. I took the largest category of firm size $\geq 10,000$ which had a frequency distribution of 10 percent. So the "top 100 firms by firm size" in 1993 should be interpreted as the top 10 percent by firm size.

The 1993 results for the sample of all executives reveal a remarkably higher ratio of lifetime workers - 78 percent among the largest firms (by firm size), and 85 percent among the top 100 firms (by capital). These executives also had considerably longer tenure of about 31 years in both categories, with a mean internal experience ratio greater than 90 percent. In comparison, Cappelli and Hamori (2004)'s estimates of lifetime workers among the sample of Fortune 100's top executives were 53 percent in 1980, and 45 percent in 2001. Mean tenure for all executives was 20.6 years in 1980 , and 15.2 years in $2001 .^{15}$ Clearly, lifetime employment among executives is more pervasive in Japan than in the U.S.

\footnotetext{
${ }^{14}$ In 1997 , firm size is recorded as its actual number, so I was able to select the top 100 firms. These were firms greater than 9,150 employees, with a mean of 21,830. In the Cappelli and Hamori (2004) sample, the means were 104,437 in 1980, and 136,614 in 2000. So the average Fortune 100 firm is considerably larger than the average "top 100" firm in Japan. Incidentally, there was only one firm with firm size greater than 100,000 in the 1997 data, which was NTT with firm size 182,482. The second largest firm was East Japan Railway with firm size 80,020 .

${ }^{15}$ Cappelli and Hamori (2004)'s sample includes a large number of missing data in executives' career histories. The proportion of lifetime workers among the sample with complete career histories was 60 percent in 1980, and 48 percent in 2001. Mean tenure should be interpreted with some caution because of the differences in mean age between executives in Japan and the U.S. Among Fortune 100 executives, mean age was 56.0 in 1980, and 51.9 in 2001, which is somewhat younger than the mean age of 57.7 among Japanese executives in 1993.
} 
The 1997 data consist of presidents only, so the results are not directly comparable to the U.S. study. ${ }^{16}$ But the results again reveal the higher proportion of lifetime workers among the largest firms in Japan. Among the top 100 firms by capital, 80 percent of presidents are lifetime workers, with an average of 90 percent internal experience.

(5) Survival rates

The survival rate is the probability of surviving beyond time $t$, or the probability of not experiencing a failure prior to $t$. In the current context, failure refers to first job separation, and the survival rate is the probability of remaining with the same job until $t$. The KaplanMeier estimate of the survival function $S(t)$ is defined:

$$
S(t)=\prod_{j \mid t_{j} \leq t}\left(\frac{n_{j}-d_{j}}{n_{j}}\right)
$$

where $n_{j}$ is the number of workers who have survived to $t_{j}$ and monotonically decreasing, and $d_{j}$ is the number of workers separated from their jobs at $t_{j}$. Alternatively, the survival function may be expressed $S(t)=\prod\left(1-\lambda_{j}\right)$ where $\lambda_{j}$ is the hazard rate of experiencing a job separation at $t_{j}$. At $t_{j}=0, d_{j}=0$, and $S(t)=1$. The starting condition is therefore that all workers are eligible for lifetime employment at the time of entry into their first jobs.

In this section, I present results from an analysis of first job separations using crosssectional microdata from the 1995 Social Stratification and Mobility Survey. The analysis is necessarily crude, as my primary objective is to estimate survival probabilities of certain categories of workers. ${ }^{17}$ Still this is a useful exercise to gain a better understanding of the

\footnotetext{
${ }^{16}$ Estimations for the sample of presidents only in the 1993 data are not available due to the small sample size of presidents in the top 100 firms.

${ }^{17}$ A more technical analysis has been undertaken by Yamaguchi $(1992,2004)$ but for male employees only. His study explores different functional forms of the hazard function in predicting the timing of first job separations.
} 
dynamics of lifetime employment, and to gain another perspective on the size of the lifetime workforce. The sample size is 1,983 consisting of men and women between the ages of 20 and 70 in the non-agricultural sector, who entered the labor force after 1945. The sample excludes the self-employed. Duration of employment until first job separation is defined as the difference between the starting age of the first job and the age of first job separation, for those who experienced a separation, or the age at the time of the survey for censored cases. Following Yamaguchi (1992), I treat employment duration greater than 30 as censored, because separations occurring after more than 30 years of employment may be due to retirement, and the data do not distinguish retirement from other types of separations. In the current sample, the starting age of employment $\left(t_{0}\right)$ is not necessarily equal to the age of school graduation $\left(t_{g}\right)$ for all respondents. Hence, the analysis fulfills condition 2 of lifetime employment, but does not fulfill condition 1. I conducted separate analysis by using the sample that fulfills this requirement $t_{0}=t_{g}$ (or Chuma [1997]'s condition where $t_{0}-t_{g} \leq 1$ ). The results were not significantly different and are not reported here.

\section{TABLE 4 ABOUT HERE}

I employ Cox proportional hazard models to predict the event of first job separations. ${ }^{18}$ The results are generally consistent with expectations (Table 4). University graduates (versus less than university) and workers in large firms and government have higher survival probabilities (indicated by their lower hazard rates), while part-time and female workers have lower survival probabilities. Cohort variables indicating the year of labor force entry show that the hazard rate has remained stable over the last 40 years.

\footnotetext{
${ }^{18}$ Parametric estimations using Weibull, Gompertz and log-normal distributions yielded similar results.
} 
The second column of Table 4 includes the interaction effect for female and marital status. Marriage affects the hazard rate asymmetrically for men and women. Married men have a lower hazard rate than do single men, while the reverse holds true for women. Married women are twice as likely to experience job separation than are married men $\left(=e^{.131+.547}\right)$. The results are generally consistent with the exit pattern of married women from the Japanese labor force. ${ }^{19}$

Kaplan-Meier survival probabilities are presented in Table 5 and Figure $2 .{ }^{20}$ On average, the proportion of workers who survived 30 years of employment with the same employer is 20 percent. We again confirm the significance of gender, education and firm size effects, with survival probabilities estimated in the expected direction. The results clearly show the high survival probabilities in large firms and the government sector. About a quarter of workers in firms $\geq 1000$ and half in government are still employed there after 30 years. Male workers in firms $\geq 1000$ and in the government sector have considerably higher survival probabilities. Separate estimates for these workers are found to be 49 percent and 65 percent, respectively.

\section{TABLE 5 ABOUT HERE}

FIGURE 2 ABOUT HERE

(6) Tenure distribution

A frequently used measure of long-term employment relationships is the mean years of tenure. According to the Wage Census data (Ministry of Health, Labor and Welfare

\footnotetext{
${ }^{19}$ Marriage is not coded as a time-varying variable in the current analysis, so the results reported here show correlations and not causations.

${ }^{20}$ Inclusion of part-time workers minimally affects the survival rates, and only at the shorter employment durations, because most part-time workers drop out before 10 years, i.e. it does not affect the survival probability of longer durations.
} 
[MHLW]), mean tenure in Japan gradually increased over the period 1980 to 2003, from 10.8 to 13.5 years for men, and from 6.1 to 9 years for women. The one caveat, however, is that average tenure does not account for population aging. MHLW statistics show that the mean age of the labor force increased from 36.8 to 40.3 years over the same period. Mandatory retirement age, which was conventionally set at 55 years, was also raised in response to population aging. 91 percent of firms now set the mandatory retirement age at 60 years compared to 55 percent in 1985 and 60 percent in 1990 (MHLW statistics 2005). The longterm effect of the aging labor force may therefore offset the modest increase in mean tenure. Evidence to this effect is documented in OECD (1997) who showed that changes in average tenure between 1985 and 1995 were statistically insignificant in Japan (and other OECD countries) after controlling for changes in age and gender composition of employment.

The aging effect becomes evident when we examine mean tenure by age groups. This is shown in Figure 3 for male employees for the period 1977 to 2003 (data for women [available from 1990 to 2003] show a similar pattern across age groups, and are not shown here). In general, the data show that mean tenure increased among the older workers, and less so among the younger workers. The increase was greatest in the age group 55 to 59 who presumably benefited most from the raising of the mandatory retirement age over this period.

Figure 3 is divided into two time periods, somewhat arbitrarily, by the vertical line which marks the year 1990. In the pre-1990 period, mean tenure increased across all age groups, except in the 30 to 34 age group. In the post-1990 period, it increased only among the older age groups (50 and over). This pattern thus implies that the rise in mean tenure since the 1990s was driven up by older workers. 
An alternative view of employment stability is to examine the share of workers under certain categories of tenure. Table 6 shows the tenure distribution of the labor force estimated from the 2000 Wage Census data. The data clearly show that employment is more stable among the larger firms. Mean tenure is longer, and the proportion of workers belonging to longer tenure categories becomes greater among larger firms.

Men have considerably longer tenure than do women. As the column "men/women ratio" indicates, women are overrepresented in the less than 1 year tenure category, and underrepresented in the longer tenure categories. The gender gap in tenure distribution is greater among the larger firms, implying that employment in large firms disproportionately favors men over women with regards to employment stability.

Following Hall (1982), I also report the distribution in the tenure 20+ category for workers aged 35 and over, since a large portion of workers under 35 could not possibly have long tenure. This simple definition fulfills condition 2 of lifetime employment (but not condition 1), and is sometimes taken as an approximation of long-term or lifetime jobs (e.g. Farber 1997). By this account, 37 percent (of workers aged 35 and over) would be counted as being employed in lifetime jobs. This proportion is highest for men employed in large firms (59 percent). However, this approximation does not account for workers who are currently working in jobs which may ultimately last twenty years or longer (Hall 1982). I address this shortcoming in the following section.

\section{TABLE 6 ABOUT HERE}

The advantage of using tenure distribution is that it is one of the few measures that allows for a consistent comparison across countries. This is demonstrated in Auer and Cazes (2000) who used ILO and Eurostat data from 1998 to estimate tenure distribution for various 
countries (Table 4). They use the Wage Census data in Japan, so the results are directly comparable to those reported in Table 6. Aging effects not withstanding, the proportion of workers with tenure of 10 years and over in Japan was 42.9 years in 1995 (not shown here), 43.2 percent in 1998 (Table 7), and 45.5 percent in 2000 (Table 6), thus indicating a modest expansion in this category. The proportion with tenure of 20 years and over was 21.4 percent in 1995 , so there was no change in this category over the 5 year period.

The data show that Japan, with average tenure of 11.6 years, is above the mean for the countries shown here, but not necessarily the country with the longest tenure. However, when broken down by gender, average tenure becomes 13.1 years for men, second only to Greece. In contrast, average tenure for women is 8.2 years, which falls below the mean for these countries. The ratio of men's average tenure to women's is 1.6 in Japan, which is the largest gender differential among these countries. The data further reinforces the gender stratified view of the Japanese labor market where men benefit from lifetime employment more than do women.

In general, low job mobility is characterized by small percentage of workers in shortlasting jobs, and large percentage of workers in long-term jobs (OECD 1986). In this regard, Japan has the lowest job mobility among the OECD states, with the lowest share of workers with tenure under 1 year, and the highest share of workers with tenure over 20 years (Figure 4, 1995 data). At the other extreme is the U.S., a high mobility country with large share of workers in short-term jobs, and small share in long-term jobs. Earlier data from OECD (1986) show a similar pattern with Japan recording the longest mean tenure, lowest share with tenure less than one year, and highest share with tenure over 20 years. Japan's standing as the low mobility country has thus persisted since the 1980 s. 


\section{FIGURE 4 ABOUT HERE}

\section{(7) Retention rates}

The retention rate is the estimated probability that a worker will remain with the same employer for a certain duration, typically 5, 10, or 15 years. Following Hall (1982), retention rates in Japan have been estimated by Hashimoto and Raisian (1985) and Kato (2001). Their main findings are reported in Table 8.

Kato (2001) examines 10 year retention rates among the civilian non-institutional population (which excludes self-employed and not in the labor force) using data from 1977 to 1997. He separates his analysis to the time period 1977 to 1987 , and 1987 to 1997 to examine employment stability in the pre-bubble versus the post-bubble periods of the 1980 s. Table 8 highlights the commonly observed pattern where retention rates become higher among the older cohorts. Workers are more likely to shop around for jobs during the early years of their career, but eventually settle down into "permanent" jobs at later stages.

Overall, Kato finds that retention rates for these two time periods remained relatively stable, and concludes that there is "little evidence for serious erosion of the practice of lifetime employment" (p.494). For example, as shown in Table 8, retention rates in the age groups 30 and above were about 80 percent for the period 1977 to 1987, and these rates changed little for the period 1987 to 1997 . In other words, about four out of five employees (with tenure greater than 5 years) retained the same job ten years later during the turbulent years of the Japanese economy. But the data do indicate setbacks in some areas. Kato explains that "the burden of downsizing during the economic slowdown in the 1990s appears to have fallen disproportionately on young employees and middle age employees with short tenure, in particular middle age female employees with short tenure" (p.495). 
Following Hashimoto and Raisian (1985), Kato also estimates 15 year retention rates in the U.S. and Japan for male employees. Results show that retention rates in Japan are significantly higher than in the U.S. in all age-tenure categories. ${ }^{21}$ According to these estimates, male employees over the age of 25 with five or more years of tenure have over a 70 percent probability of remaining with the same employer 15 years later in Japan, but this probability falls to 47 percent in the U.S. The results also show that retention rates remained remarkably stable in both countries over the last 35 years. ${ }^{22}$

\section{TABLE 8 ABOUT HERE}

In 1997, the OECD estimated 5 year retention rates among their member states (OECD 1997). The results show that Japan, at 64.2 percent, had the highest 5 year retention rate in the world (followed by Germany [60.7 percent] and Switzerland [55.2 percent]). The results therefore further support the stability of employment relationships in Japan.

(8) Number of jobs held

Another measure of job mobility is the number of jobs held by the average worker. Originally proposed by Hall (1982), and later replicated by Hashimoto and Raisian (1985) and others, the hypothetical number of jobs by a worker of given age can be estimated as:

Cumulative number of $=$ Cumulative number of jobs held by age group $(i-1)$

jobs held by age group $(i)=+\{$ Accession rate in age group (i) $\times$ Number of year intervals in age group $(i)\}$

\footnotetext{
${ }^{21}$ Koike (1977) uses 1962 data and reports that the tenure of 15 years and over is more common in the U.S. than in Japan. However, Hashimoto and Raisian (1985) argue that this is misleading because lifetime employment became widespread only after the mid-1950s.

${ }^{22}$ For a more elaborate estimation of retention rates in the U.S., see Diebold, Neumark and Polsky (1997) and Neumark, Polsky and Hansen (1999).
} 
where the accession rate refers to the number of new hires divided by the number of employed persons. Accession rates are discussed in further detail below. This is a straightforward estimation method which can be conducted for any year using published government data. However, because the data are cross-sectional, it is interpreted as the hypothetical number of jobs the average worker would expect to have, if year and cohort effects were not present (Flath 2000).

Estimation results for male workers are reported in Table 9a. Results for 1977 indicate that the average male worker would have experienced approximately five jobs by the time he reaches the age of 64 . In the U.S., this number was eleven jobs (for male workers in 1978, estimated by Hashimoto and Raisian 1985). Comparable estimates are also available from Britain, but for both men and women. According to Gregg and Wadsworth (1995)'s estimations, the average British worker would have experienced 10.7 jobs over the working life (by the age of 64) in 1989, and 8.4 in 1993. Although not shown here, my estimates for both men and women were 8.6 jobs in 1991 and 7.6 jobs in 1995 . These results suggest that job mobility has remained lower in Japan compared to the U.S. and Britain. ${ }^{23}$

In Japan, the cumulative number of jobs increases to about eight in 1991 and also in 2003. While these numbers point to an overall increase in job mobility compared to 1977 , the data also indicate that this increase was largely affected by the mobility of younger workers (and to some extent older workers in age group 55 to 64). The proportion of young workers starting new jobs increased considerably in the youngest age category of 16 to 19 which drives up the predictions. In 1977, the average male worker would have experienced .8 jobs by the age of 19 versus 2.5 jobs in the 1990s and 2003. Stated another way, he would have experienced 16 percent of the eventual number of jobs by the time he reaches 19 in 1977, and over 30 percent in the 1990s and 2003. Hence, if we exclude the age 16 to 19 category from

\footnotetext{
${ }^{23}$ Earlier data from 1966 using the same estimation method show that the cumulative number of jobs for male worker at the age of 64 was 4.2 in Japan, and 10.2 in the U.S. (data cited in Flath [2000]).
} 
Table 9a, the results would indicate only a modest increase in the number of jobs held, from about four in 1977, to about five in the 1990s and 2003.

\section{TABLES 9a AND 9b ABOUT HERE}

Table $9 \mathrm{~b}$ reports the actual number of jobs held in Japan and the U.S. The results in the U.S. are direct responses to the question, "For how many employers have you ever worked full time?” taken from the 1998 General Social Survey. The results in Japan were estimated from detailed work history data available from the 1995 Social Stratification and Mobility Survey. The last two rows of Table $9 \mathrm{~b}$ also report the percentage of workers who have never changed jobs, or workers who have worked for only one employer. I report the percentages for the age group 50 to 54 as a rough approximation of workers who are close to reaching retirement. ${ }^{24}$ Both samples consist of respondents who are currently employed in part-time or full-time positions, and exclude the self-employed. ${ }^{25}$

The results further highlight the stability of employment relationships in Japan relative to the U.S. With the exception of men in the 20 to 24 age group, the number of fulltime jobs held by the U.S. worker is roughly double the number held by the Japanese worker at any given age level. The proportion of workers who have never changed jobs (in the age group 50 to 54 ) is 19.6 percent in Japan versus 5.0 percent in the U.S. In the case of Japan, I also report the same proportion who may have been in either full-time or part-time jobs. This proportion remains the same for men, but increases by 4.7 percent for women. In other words,

\footnotetext{
${ }^{24}$ One caveat is that both samples include workers who started working at any age. This was not a significant setback in Japan. In separate analysis, I confirm that 98 percent of workers were employed before the age of 25 . I was unable to confirm this in the GSS data because the age of labor market entry is not recorded.

${ }^{25}$ This condition eliminates workers who may have been employed previously, but are not currently working. This is a required condition since we want to estimate the proportion of workers who have survived job separations until reaching retirement age.
} 
4.7 percent of women (in the age group 50 to 54) have been employed in part-time positions "for life" versus zero percent for men.

\section{(9) Separation rates}

The separation rate is defined as the total number of separations divided by the total number of employed persons. ${ }^{26}$ It is a general measure that captures the outflow of workers. The total separation rate changed very little in Japan over the time period 1991 to 2003 (Table 10). However, the total rate masks the considerable variation in separations across age groups (Figure 5), a topic addressed below. The data show that women are more likely to be separated from their jobs than are men. The separation rate remained stable for regular workers, but increased modestly for part-time workers. The separation rate for firm size $\geq$ 1000 shows that the flow of workers out of large firms also increased during this period. Separation rates for men only in this category show a similar increase, indicating a pattern of increasing separations from the core. ${ }^{27}$

Table 10 also shows the separation rates by sex and reasons for separations. Here, the reported numbers represent the job separations for each category as the percentage of the total number of separations (and not the total number of employed persons). "Transfers" is shown in parenthesis because this is a sub-category of separations due to "employer's discretion." Likewise, "marriage, childbearing and homecare" is a sub-category under "personal reasons." The sum of all categories minus these two sub-categories equals 100 percent. MHLW's classification of involuntary separation includes expiration of contract,

\footnotetext{
${ }^{26}$ Separation rates are sometimes taken to be synonymous with turnover rates (e.g. Blinder and Krueger 1996), but they are distinct concepts. Turnover rate involves both accessions and separations. We may refer to turnover rates as separation rates, if we assume that accessions equal separations.

${ }^{27}$ Firm size categories reported in the Employment Trends Survey (MHLW) are not consistent with those reported in the Labor Force Survey (MIC statistics). Firm size category $\geq 500$, for example, is not available in the Employment Trends Survey.
} 
employer's discretion (including transfers), and mandatory retirement. Voluntary separations are separations for personal reasons.

In general, voluntary and involuntary separations move in opposite directions voluntary separations are pro-cyclical, and involuntary separations are counter-cyclical. Table 10 shows a trendline of increasing involuntary separations and decreasing voluntary separations, a pattern that suggests that separations were affected by the economic downturn of the 1990s. The most conspicuous trend is the increasing proportion of separations due to the employer's discretion. Overall, this rate has more than doubled for both men and women. Whether transfers should be counted as involuntary or not depends on the nature of the transfer, but their exclusion results in a similar increasing pattern over these years. Separations due to mandatory retirement also increased during the same period. This upward trend is expected to continue in the foreseeable future against the backdrop of the aging workforce.

The most noticeable distinction between the sexes is that women are significantly more likely to separate for marriage, childbearing and homecare. Although this proportion has declined, 10 percent of all separations among women are still due to their having to take on family obligations. In contrast, this proportion is virtually zero for men.

TABLE 10 ABOUT HERE

FIGURE 5 ABOUT HERE

Although not shown here, involuntary separation rates as the percentage of the total number of employed persons also indicates an upward trend, from 2.6 in 1988 to 4.2 in 2003 (MHLW statistics). For men, these rates increased from 2.5 to 4.1, and for women, from 2.4 
to 3.8 over these years. ${ }^{28}$ Despite the small proportion, these estimates suggest that involuntary separations have risen over time, both in absolute and in relative terms.

Figure 5 shows separation rates by age categories for men only (data for women were roughly similar to men's and are not reported here). We observe the general lifecycle pattern of job mobility - high separation rates among the young and the old, and the low separation rates in the middle categories. Separation rates among the age groups 25 to 59 remained virtually flat during this period. Separation rates for the age groups 60 and over show some fluctuations reflecting an increasing pattern of job mobility among workers in post-retirement.

The greatest change was recorded by the youngest age category of 19 and under, from 27.4 percent in 1991 to 42.2 percent in 2003 (and from 22.9 percent to 47.8 percent for women). This upward trend is consistent with the so-called 7-5-3 phenomenon which was coined in the 1990s to depict the high rate of job separations among the youth. The expression describes the emerging pattern where approximately 70 percent of middle school graduates, 50 percent of high school graduates, and 30 percent of college graduates are separated from their jobs within three years.

An international comparison of separation rates is available from OECD for various years. In the 1980s, separation rates in Japan were lowest among the countries surveyed while they were highest in the U.S. (OECD 1986). More recent data show separations due to both layoffs (= involuntary separations) and quits (= voluntary separations) as the proportion of total employment (OECD 1997). The separation rates for Japan under this category were 1.9 in the $1980 \mathrm{~s}$, and 2.4 in the 1990s. In both periods, these numbers were far below the average recorded in the EU (2.7 and 4.4), and in the U.S. (5.1 and 4.0). Moreover, separation

\footnotetext{
${ }^{28} 1988$ estimates for men and women are taken from Rebick (2001). Total number of employed persons does not include workers in construction. The Employment Trends Survey did not include construction workers prior to 1991. To account for this change in sampling, Rebick excludes construction workers for the sample of workers after 1991. I calculated the involuntary separation rates for 2003 using the same estimation method as Rebick.
} 
rates due to layoffs in Japan were the lowest among all OECD member states in both periods. Involuntary job separations may be on the rise in Japan, but they are still far less common than they are in other countries.

\section{(10) Accession rates}

The accession rate measures the flow of workers into employment, and is defined as the number of new hires divided by the number of employed persons. The total accession rate shows some fluctuations during the period 1991 to 2003 with an overall modest decrease. Women have higher accession rates than do men. Taken together with their higher separation rates (Table 10), the data further suggest a higher incidence of labor mobility among women

relative to men. Accession rates declined by over 3 percentage points for regular workers, but only by .2 percentage points for part-time workers. Data for firm size $\geq 1000$ - for both the total and for men only - show that accession to the core is now less probable than before.

The denominator for accession and separation rates are the same, and this allows us to look at the difference between the inflow and outflow of workers. In Table 11, the minus sign shows a "mobility deficit" where separations were greater than accessions. With the exception of 1991, the results indicate an overall mobility deficit during the 1994 to 2003 period. The mobility deficit for regular workers and for workers in large firms accompanied by an overall mobility surplus among part-time workers suggests that the core workforce is shrinking.

Finally, I examine accession rates at the entry level for newly graduating students. I use the expression "new" school graduates to distinguish those who have just graduated from those graduates who are already employed. The data indicate a diminishing flow of new recruits into the core. Accession rates for new university graduates by firm size show a conspicuous trendline - decreasing probability of entry into the large firms $(\geq 1000)$ 
accompanied by an increasing probability of entry into small firms. Accession rates into "freeter" status (which includes part-time and temporary workers) also clearly indicate that both high school and university graduates are now significantly more likely to be hired into nonstandard employment.

In sum, we observe a declining flow of new recruits into the core, and an increasing flow of new graduates into nonstandard employment. The expansion of nonstandard employment among the youth population in the 1990s invariably led to their higher job separations (Figure 5). The declining share of standard workers in the labor force (Figure 1) is to a large extent attributable to the increasing flow of young workers into nonstandard employment.

\section{TABLE 11 ABOUT HERE}

\section{Summary and Discussion}

So how big is lifetime employment in Japan? While lifetime employment is often touted as one of the main pillars of the Japanese employment system, in practice, it applies only to a small proportion of the labor force. My estimations based on various methods point to roughly 20 percent: (i) The ex-ante measure of the core workforce, which assumes that lifetime employment coverage is limited to male standard workers in large firms $(\geq 500)$ and in government, is 19 percent; (ii) The proportion of lifetime workers defined as those in the age group 50 to 54 who have never left their employers since school graduation, is 18 percent; (iii) The probability of surviving job separations for 30 years is 20 percent; and (iv) The proportion of workers in the age group 50 to 54 who have never experienced job separations is 22 percent. 
Yet, the lifetime employment rate varies considerably by gender, firm size, and education level. My analysis solidly confirms the generalized view that female workers do not benefit from the lifetime employment system, while male workers in large firms (and in government) are most likely to be covered by it. At its extreme, the proportion of lifetime workers among male university graduates in large firms is 55 percent, and the 30 year survival probability of male workers in government is 65 percent.

How unique is lifetime employment in Japan? If lifetime employment is taken as a generalized practice of long-term employment, then the practice is more pervasive in Japan than in other countries. Job mobility in Japan remains one of the lowest among the OECD member countries, as characterized by the following features: (i) the highest proportion of workers with tenure longer than 20 years; (ii) lowest proportion of workers with tenure less than one year; (iii) highest 5 year retention rate; (iv) lowest separation rate; and (v) lowest involuntary separation rate. At the opposite end of the scale lies the U.S., characterized by high job mobility. By any measure, job mobility is much higher in the U.S. than in Japan. Comparison of job mobility between these two countries should thus be understood as a comparison of two extremes.

And, how has lifetime employment changed over time? I present a summary table of the various estimations in Table 12. Changes in lifetime employment are shown under the column "lifetime employment" where the $(+)$ sign indicates support for it and the $(-)$ sign indicates its decline. The results are mixed. Overall, the decline in the core workforce, standard employment, and full-time employment (as the share of total employment) suggests a decline in lifetime employment. On the other hand, the proportion of lifetime workers, and the probability of surviving job separations show an upward trend or no change. The two are not necessarily conflicting findings but require some elaboration. 
TABLE 12 ABOUT HERE

Much of the disagreement regarding changes in lifetime employment stems from confounding or not disaggregating the inflow, outflow and the stock of workers. One interpretation is that although the population of workers who are ex-ante covered by lifetime employment may be shrinking, the likelihood of job separations has remained stable for those who are already in the system. Consider the analogy between the labor force and the bathtub where the water flowing into the tub represents the flow of workers into the core, water flowing out is the flow of workers out of the core, and the water level in the tub is the employment level (or the stock) of the core workforce. In this analogy, the water level remains the same or decreases because: (i) There is little water being eliminated from the tub; and, (ii) Preserving the current water level requires choking off the flow of water into the tub. The mobility measures add support to this effect. In the 1990s, new graduates were significantly less likely to enter the labor force as standard workers than in previous periods. This led to two outcomes. First, standard employment declined relative to nonstandard employment, which led to an overall reduction of the core workforce. And second, the expansion of the nonstandard workforce among younger workers resulted in their higher job mobility (as characterized by their lower retention rates and higher separation rates). In contrast, job mobility among older workers remained virtually unchanged during the 1990s (with the exception of the post-retirement age group).

Taken together, we observe a pattern of bifurcation between good jobs and bad jobs, or more specifically, young persons entering bad jobs, and older persons remaining in good jobs. This has resulted in the erosion of employment stability among young workers and its resilience among older workers. The ongoing debate concerns whether this outcome is attributable to changes in the supply side or the demand side. The consensus is shifting 
towards the latter. A modest increase in involuntary job separations accompanied by a decrease in voluntary separations suggests that job mobility was affected by the economic conditions of the 1990s. Outside employment prospects for those who were already in the core were not favorable, so the core workers held on to their jobs. The firms responded by avoiding dismissals to the fullest extent possible, and instead cut back on recruitment of new graduates. Genda (2001) surmises that the adverse conditions of youth employment in the 1990s were the consequence of overly emphasizing the employment protection of middle- to older workers. The economic downturn triggered a hiring freeze where employers prioritized the protection of their core workers at the expense of new hires. The statistics show that many of the new graduates became freeters involuntarily; they prefer standard employment, but were unable to do so because of unfavorable demand-side conditions. ${ }^{29}$

Meanwhile, survey results from both workers and employers indicate strong support for the lifetime employment system. In fact, the support base seems to be increasing. A worker survey conducted in 2004 shows that 78 percent of workers are in favor of lifetime employment, an increase of 5.7 percent from the first survey conducted in 1999 (JILPT $2005 b) .{ }^{30}$ Older workers are more likely to support the system, presumably because they are more likely to benefit from it, but the majority of the younger workers also show support for it (64.2 percent of males and 66.4 percent of females in their 20s). On the employer's side, survey results from 1999 show that 60.6 percent of personnel managers intend to "maintain lifetime employment as much as possible," an increase from the 46.8 percent reported in

\footnotetext{
${ }^{29}$ The youth unemployment rate (age group 15 to 24) climbed from 4.3 to 9.6 percent between 1990 and 2001, while the corresponding numbers for the age group 45 to 54 were 1.2 and 3.5 percent (MIC statistics, various years). Citing MHLW statistics, Genda (2001) explains that the proportion of "freeters" who actively sought but could not find full-time employment increased from 10 to 26 percent between 1989 and 1997, while the proportion who had no intention to work full-time decreased from 22 to 14 percent during the same period. He also shows that firms with higher proportion of older workers were less likely to hire new graduates during the 1990s. For further description of the freeter and jobless youth issues, see JILPT (2005a).

${ }^{30}$ Survey conducted by the Japan Institute for Labor Policy and Training (JILPT). Response rate in support for lifetime employment is the proportion of workers who responded that lifetime employment is "good" or "better than the alternative."
} 
1997..$^{31}$ These survey results are strong counterevidence to the anecdotal view that lifetime employment is a thing of the past. Workers - both the young and the old - desire employment security, and employers still feel obliged to preserve the system.

From an incentive perspective, it can be argued that lifetime employment will maintain its resilience as long as it acts as an incentive device. Emphasis on nativity in promotion decisions among managers and executives shows no signs of decline; if anything, it is now more important than before. As long as this promotion practice persists, loyalty and commitment will remain the norm, and there will be no incentive to seek outside employment opportunities.

The incentive among top executives is also aligned to protect the employment of their workers. The 1993 survey of executives (cited previously) asked the question, "What is your most important mission as a company executive?" Noda (1995) ranks the possible responses, then predicts their effects on executive compensation. The top response was, "to protect the employment and lifestyle of workers" (response rate 41 percent). Moreover, this response was linked to higher executive compensation. In contrast, "to improve returns to shareholders" was a distant eighth (response rate 6 percent), and this response had no effect on compensation. The findings highlight the conventional wisdom that Japanese firms are not run in the interest of shareholders but in the interest of protecting their human resources (Ahmadjian and Robbins 2005; Milgrom and Roberts 1992). The priorities and incentives among executives are aligned to maintain the lifetime employment system.

An ingrained feature of native workers is that they have the longest tenure in their age group. In theory, this implies that native workers have accumulated the maximum attainable level of firm-specific skills among their co-workers. As long as the returns to tenure remain positive, this relationship predicts that native workers will always earn higher

\footnotetext{
${ }^{31}$ Survey on Changes in the Japanese Personnel System conducted by the Japan Productivity Center for SocioEconomic Development, cited in MHLW (2001).
} 
wages than non-natives, ceteris paribus. Empirical evidence from the Wage Census data shows that the tenure effect, or more generally the seniority effect on wages, declined throughout the 1980s (Clark and Ogawa 1992; Genda 1998). ${ }^{32}$ The incentive to remain with the firm may therefore be diminishing, which would predict a downward trend in lifetime employment in the long-run. However, my analysis (also using the Wage Census data) shows that the proportion of lifetime workers increased during the same period under which the seniority effect on wages declined. Moreover, the possibility of losing returns to seniority and the fear that their skills may not be transferable to other firms remain two of the top reasons that workers do not change jobs in Japan (Moriguchi and Ono, forthcoming; Ono and Rebick 2003). The incentives underlying the Japanese employment system may not be as straightforward as can be predicted under conventional economic intuition.

This paper has examined the various concepts and measurements involved in estimating the lifetime employment rate. I have documented various measures regarding the size of the lifetime workforce, its uniqueness in the international context, and its changes over time. The estimations depend critically on the definitions and underlying assumptions. They also depend on the time period, demographic group, and labor market sector. I intentionally avoided segmenting the labor force into finer units as this would exponentially broaden the scope of my analysis. Lifetime employment rates vary across industries, union versus nonunion settings, occupations, and by other employer and employee attributes, but I reserve these questions for future research.

\footnotetext{
${ }^{32}$ Genda (1998) also shows that the tenure effect on promotion rates into management positions was lower in 1992 compared to 1980 .
} 


\section{References}

Abegglen, James C. 1958. The Japanese Factory: Aspects of Its Social Organization. Cambridge: MIT Press. Abegglen, James C. and George Stalk, Jr. 1985. Kaisha, The Japanese Corporation. New York: Basic Books. Ahmadjian, Christina L. and Gregory E. Robbins. 2005. "A Clash of Capitalisms: Foreign Shareholders and Corporate Restructuring in 1990s Japan.” American Sociological Review 70: 451-471.

Aoki, Masahiko. 1992. Information, Incentives, and Bargaining in the Japanese Economy. Cambridge: Cambridge University Press.

Ariga, Kenn, Giorgio Brunello, and Yasushi Ohkusa. 2000. Internal Labor Markets in Japan. Cambridge: Cambridge University Press.

Auer, Peter and Sandrine Cazes. 2000. "The Resilience of the Long-term Employment Relationship: Evidence from the Industrialized Countries." International Labour Review 139: 379-408.

Bronfenbrenner, Martin and Yasukichi Yasuba. 1987. "Economic Welfare." In The Political Economy of Japan, Volume 1: The Domestic Transformation. Edited by Kozo Yamamura and Yasukichi Yasuba. Stanford: Stanford University Press. Pp. 93-136.

Cappelli, Peter and Monika Hamori. 2004. "The Path to the Top: Changes in the Attributes and Careers of Corporate Executives, 1980-2001.” NBER Working Paper Series w10507.

Center for Public Resources Development. 2003. Kigyo no shakaisei ni kansuru chosa (Survey on corporate responsibility). Tokyo: Center for Public Resources Development.

Chuma, Hiroyuki. 1997. "Keizai kankyo no henka to chukonenso no choukinzokuka" (Change in the economic environment and lengthening of tenure for the middle and older age groups). PP. 47-82. In Koyo kanko no henka to josei rodo (Changing employment practices and female labor force). Edited by Hiroyuki Chuma and Terukazu Suruga. Tokyo: University of Tokyo Press.

Clark, Robert L. and Naohiro Ogawa. 1992. "Employment Tenure and Earnings Profiles in Japan and the United States: Comment." American Economic Review 82: 336-345.

Cole, Robert E. 1979. Work, Mobility and Participation: A Comparative Study of American and Japanese Industry. Berkeley: University of California Press.

Diebold, Francis X., David Neumark and Daniel Polsky. 1997. “Job Stability in the United States.” Journal of Labor Economics 15: 206-233.

Dore, Ronald P. 1973. British Factory - Japanese Factory: The Origins of National Diversity in Industrial Relations. Berkeley: University of California Press.

Farber, Henry. 1997. "Trends in Long-term Employment in the United States, 1979-1996." Princeton University Industrial Relations Section Working Paper 384.

Flath, David. 2000. The Japanese Economy. New York: Oxford University Press.

Form, William. 1979. "Comparative Industrial Sociology and the Convergence Hypothesis." Annual Review of Sociology 5: 1-25.

Genda, Yuji. 1998. "Japan: Wage Differentials and Changes since the 1980s.” Pp. 35-71. In Wage Differentials: An International Comparison. Edited by Toshiaki Tachibanaki. London: Macmillan Press. 2001. Shigoto no naka no aimai na fuan (A nagging sense of job insecurity). Tokyo: Chuokoron shinsha.

Gregg, Paul and Jonathan Wadsworth. 1995. "A Short History of Labour Turnover, Job Tenure, and Job Security." Oxford Review of Economic Policy 11: 73-90.

Hall, Robert E. 1982. "The Importance of Lifetime Jobs in the U.S. Economy." American Economic Review 72: 716-724.

Hashimoto, Masanori and John Raisian. 1985. "Employment Tenure and Earnings Profiles in Japan and the United States.” American Economic Review 75: 721-735.

Ishikawa, Tsuneo and Takahisa Dejima. 1994. "Rodo shijo no niju kozo" (Dual structure of the labor market). Nihon no shotoku to tomi no bunpai (Distribution of Wealth and Income in Japan). Pp.169-209. Tokyo: University of Tokyo Press.

Itoh, Hideshi. 1991. "Japanese Human Resource Management from the Viewpoint of Incentive Theory." Ricerche Economiche 45: 345-376.

Itoh, Hideshi and Hiroshi Teruyama. 1995. "Kaisha yakuin no ishiki to mokuteki” (Attitudes and objectives of corporate executives). PP. 61-79. In Shoshin no keizaigaku (The economics of promotion). Edited by Toshiaki Tachibanaki and Research Institute for Advancement of Living Standards. Tokyo: Toyokeizai shinposha.

Japan Institute for Labour Policy and Training (JILPT). 2005a. Labor Situation in Japan and Analysis: Detailed Exposition 2005/2006. Tokyo: JILPT. .2005b. "Signs of a Favorable Reappraisal of Japanese-style Employment Practices." Japan Labor Flash No.37 (May 2, 2005).

Kato, Takao. 2001. "The End of Lifetime Employment in Japan?: Evidence from National Surveys and Field Research." Journal of the Japanese and International Economies 15: 489-514. 
Koike, Kazuo. 1977. Shokuba no Rodo Kumiai to Sanka (Trade union and participation on the shop floor). Tokyo: Tokyo Kezia Shimpo Sha.

1980. "Nihonteki Koyo Kanko" (The Japanese Employment Practice). In Keizaigaku Daijiten II

(Encyclopedia of Economics Vol.II). pp. 100-108. Tokyo: Toyokeizai Shimpo Sha.

Milgrom, Paul and John Roberts. 1992. Economics, Organization, and Management. Englewood Cliffs: Prentice-Hall.

Ministry of Labor. 1993. Rodo Hakusho (White Paper on the Labor Economy). Tokyo: Ministry of Labor.

Ministry of Health, Labour and Welfare (MHLW). 2001. Kosei Rodo Hakusho (White Paper on Health, Labor and Welfare). Tokyo: MHLW.

Moriguchi, Chiaki and Hiroshi Ono. "Japanese Lifetime Employment: Response to Crisis in Historical Perspective." Forthcoming in Institutional Change in Japan: Why It Happens, Why It Doesn't. Edited by Magnus Blomström and Sumner La Croix. London: Routledge.

Neumark, David (Ed). 2000. On the Job: Is Long-Term Employment a Thing of the Past? New York: Russell Sage.

Neumark, David, Daniel Polsky and Daniel Hansen. 1999. "Has Job Stability Declined Yet? New Evidence for the 1990s." Journal of Labor Economics 17: S29-S64.

Noda, Tomohiko. 1995. "Kaisha yakuin no shoshin to houshu kettei” (Determinants of promotion and compensation among corporate executives). PP. 39-60. In Shoshin no keizaigaku (The economics of promotion). Edited by Toshiaki Tachibanaki and Research Institute for Advancement of Living Standards. Tokyo: Toyokeizai shinposha.

Ohkochi, Kazuo. 1972. Roshi kankei ron no shiteki hatten (Historical development of labor relations). Tokyo: Yuhikaku.

Ohtake, Fumio. 2001. Koyo mondai wo kangaeru (Employment-related problems in Japan). Osaka: Osaka University Press.

Ono, Akira. 1989. Nihonteki koyo kanko to rodo shijo (Japanese employment practices and the labor market). Tokyo: Toyo keizai shinposha. . 1997. "Haenuki toyo no kotai to naibu rodo shijo no henshitu" (Changing internal labor markets and the narrowing of the gap in promotion rates between lifetime employees and mid-career hires). pp.83-113. In Koyo kanko no henka to josei rodo (Changing employment practices and female labor force). Edited by Hiroyuki Chuma and Terukazu Suruga. Tokyo: University of Tokyo Press.

Ono, Akira and Eiji Shiraishi. 1993. "Amerika kigyo oyobi zaibei nikkei kigyo no koyokanko" (Employment practices of U.S. and Japanese firms based in the U.S.). Japan Institute of Labor Report 48: 2-43.

Ono, Hiroshi and Marcus E. Rebick. 2003. "Constraints on the Level and Efficient Use of Labor." Pp. 225-257. In Structural Impediments to Japan's Economic Growth. Edited by Magnus Blomström, Jennifer Corbett, Fumio Hayashi and Anil Kashyap. Chicago: NBER and University of Chicago Press.

Organisation for Economic Co-operation and Development (OECD). 1986. Flexibility in the Labour Market: The Current Debate. Paris: OECD. 1997. Employment Outlook. Paris: OECD. 2003. Employment Outlook. Paris: OECD.

Rebick, Marcus E. 1993. "The Persistence of Firm-Size Differentials and Labor Market Segmentation in Japan." Journal of the Japanese and International Economies 7: 132-156. .2001. "Japanese Labor Markets: Can We Expect Significant Change?” Pp. 120-141 in Japan's New Economy: Continuity and Change in the Twenty-First Century, edited by Magnus Blomström, Byron Gangnes, and Sumner La Croix. Oxford: Oxford University Press. 2005. The Japanese Employment System. Oxford: Oxford University Press.

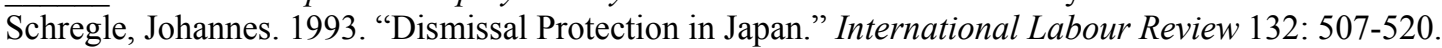

Tachibanaki, Toshiaki. 1984. "Labor Mobility and Job Tenure." Pp. 77-102. In The Economic Analysis of the Japanese Firm. Edited by Masahiko Aoki. Amsterdam: Elsevier Science Publishers.

Tachibanaki, Toshiaki and Souichi Ohta. 1994. "Wage Differentials by Industy and the Size of Firm, and Labour Market in Japan." In Labour Market and Economic Performance: Europe, Japan and the USA. Edited by Toshiaki Tachibanaki. New York: St. Martin's Press. Pp. 56-92.

Taira, Koji. 1962. "The Characteristics of Japanese Labor Markets." Economic Development and Cultural Change 10: 150-168.

Yamaguchi, Kazuo. 1992. "Accelerated Failure-Time Regression Models with a Regression Model of Surviving Fraction: An Application to the Analysis of 'Permanent Employment' in Japan." Journal of the American Statistical Association 87: 284-292. 2004. "Shuhin koyo no jittai to sono henka - Sengo kara 1995 nen made no doko" (The state of lifetime employment and its changes). RIETI discussion paper series 04-J-044.

Wailerdsaka, Natenapha and Akira Suehiro. 2004. "Top Executive Origins: Comparative Study between Japan and Thailand." Asian Business and Management 3: 85-104. 
Table 1 Concepts and measurements of lifetime employment

\begin{tabular}{|c|c|c|}
\hline Source & Concept / Definition & Estimates \\
\hline $\begin{array}{l}\text { Labor market segmentation } \\
\text { Taira (1962) }\end{array}$ & $\begin{array}{l}\text { (R)eview of the postwar Japanese labor markets shows } \\
\text { that the appropriateness of the "permanent" status is } \\
\text { limited to the permanent, unionized employees of the } \\
\text { high-wage, large firms, who can be identified with the } \\
\text { permanent regulars in the firms employing } 500 \text { or } \\
\text { more regular workers. (p.167) }\end{array}$ & $\begin{array}{l}\text { No more than a fifth } \\
\text { of all wage-earners in } \\
\text { Japanese } \\
\text { manufacturing. }\end{array}$ \\
\hline Dore (1973) & $\begin{array}{l}\text { Employment institutions characteristic of the } \\
\text { 'Japanese system' are found in (a) government } \\
\text { employment, (b) firms with more than } 500 \text { employees, } \\
\text { (c) a fair but not easily estimated proportion of } \\
\text { enterprises with one to five hundred employees, } \\
\text { especially in the white collar industries - and in those } \\
\text { manufacturing establishments, perhaps about a quarter } \\
\text { of the total, which have trade unions. (pp.304-305) }\end{array}$ & $\begin{array}{l}\text { Half of the total } \\
\text { number of } \\
\text { employees, or about } \\
\text { one-third of all those } \\
\text { gainfully occupied in } \\
\text { the Japanese } \\
\text { economy. }\end{array}$ \\
\hline Cole (1979) & $\begin{array}{l}\text { (In response to Dore [1973]) } \\
\text { If one accepts, as seems reasonable, that females are } \\
\text { almost totally excluded from the experience of } \\
\text { permanent employment, then one ought to use the total } \\
\text { labor force (and not just males) as the denominator to } \\
\text { determine the scope of permanent employment. (p.61) }\end{array}$ & $\begin{array}{l}32 \text { percent of all } \\
\text { employees, or } \\
20 \text { percent of those } \\
\text { gainfully employed. }\end{array}$ \\
\hline Abegglen and Stalk (1985) & $\begin{array}{l}\text { It has been suggested that some } 30 \text { percent of the } \\
\text { Japanese labor force is covered by the system of } \\
\text { permanent employment, but it appears that this } \\
\text { estimate derives from the fact that } 30 \text { percent of the } \\
\text { labor force is unionized. The system is by no means } \\
\text { coterminous with unionization. (p.201) }\end{array}$ & N.A. \\
\hline Ministry of Labor (1993) & $\begin{array}{l}\text { We estimate the proportion of employees covered by } \\
\text { lifetime employment to be: (1) male regular workers } \\
\text { in the non-agricultural sectors employed in firms with } \\
\text { at least } 500 \text { regular workers; (2) male regular workers } \\
\text { employed in the government sector; divided by (3) } \\
\text { total number of workers employed in the non- } \\
\text { agricultural sectors. (p. } 248)\end{array}$ & $\begin{array}{l}23.4 \text { percent in } 1985 \\
21.6 \text { percent in } 1991\end{array}$ \\
\hline
\end{tabular}


Table 1 Concepts and measurements of lifetime employment (continued)

\begin{tabular}{|c|c|c|}
\hline Source & Concept / Definition & Estimates \\
\hline $\begin{array}{l}\text { Ex-post method } \\
\text { Abegglen (1958) }\end{array}$ & $\begin{array}{l}\text { At whatever level of organization in the Japanese } \\
\text { factory, the worker commits himself on entrance to the } \\
\text { company for the remainder of his working career. The } \\
\text { company will not discharge him even temporarily } \\
\text { except in the most extreme circumstances. He will not } \\
\text { quit the company for industrial employment } \\
\text { elsewhere. He is a member of the company in way } \\
\text { resembling that in which persons are members of } \\
\text { families, fraternal organizations, and other intimate } \\
\text { and personal groups in the United States. (p.11) }\end{array}$ & N.A. \\
\hline Ohkochi (1972) & $\begin{array}{l}\text { Permanent employment does not simply imply a long- } \\
\text { term employment relationship. Firms hire workers } \\
\text { and "raise them from their infancy" (kogai) to become } \\
\text { employees who will continue to work with the firm } \\
\text { until mandatory retirement age. It means that, whether } \\
\text { they be shop-floor workers or clerical workers, they } \\
\text { will remain with the firm for a long duration, and } \\
\text { continue to work within the firm. (p.178) }\end{array}$ & N.A. \\
\hline Cole (1979) & $\begin{array}{l}\text { Permanent employment refers to the practice whereby } \\
\text { an employee enters a company after school graduation, } \\
\text { receives in-company training, and remains an } \\
\text { employee of the same company until the retirement } \\
\text { age of fifty-five. (p.11) }\end{array}$ & N.A. \\
\hline Koike (1980) & $\begin{array}{l}\text { Workers become employed right after their graduation } \\
\text { from school with a particular company. The employer } \\
\text { will not lay off his workers if possible even in the } \\
\text { course of depression. The employee in turn will not } \\
\text { quit his job at this company but tends to continue } \\
\text { working there until he reaches his retirement age. }\end{array}$ & N.A. \\
\hline Ono (1997) & $\begin{array}{l}\text { (In response to Ohkochi [1972]) } \\
\text { There are three essential elements to the concept of } \\
\text { lifetime employment. First, workers must enter the } \\
\text { firm immediately following school graduation - no } \\
\text { gaps are allowed between graduation and firm entry. } \\
\text { Second, workers are hired with the implicit } \\
\text { understanding that their employment will be secured } \\
\text { until mandatory retirement. And third, lifetime } \\
\text { employment applies to all workers regardless of } \\
\text { employment status or occupation. }\end{array}$ & (see text) \\
\hline
\end{tabular}


Table 2 Proportion of lifetime workers to the total number of employed persons (percentages)

\begin{tabular}{|c|c|c|c|c|c|}
\hline & $1980^{\mathrm{a}}$ & 1985 & 1990 & 1995 & 2000 \\
\hline \multicolumn{6}{|l|}{ Men } \\
\hline 30 to 34 & 33.1 & 34.3 & 34.6 & 33.6 & 33.5 \\
\hline 35 to 39 & 18.6 & 27.7 & 30.2 & 30.3 & 31.2 \\
\hline 40 to 44 & 14.9 & 21.1 & 25.6 & 27.6 & 29.1 \\
\hline 45 to 49 & 11.0 & 14.3 & 20.2 & 23.8 & 27.0 \\
\hline 50 to 54 & 9.8 & 9.8 & 12.9 & 17.4 & 22.8 \\
\hline \multicolumn{6}{|l|}{ Women } \\
\hline 30 to 34 & 21.7 & 18.5 & 20.6 & 22.6 & 27.4 \\
\hline 35 to 39 & 6.3 & 7.9 & 12.3 & 14.4 & 17.7 \\
\hline 40 to 44 & 2.9 & 3.9 & 6.0 & 8.2 & 12.0 \\
\hline 45 to 49 & 2.0 & 2.0 & 3.2 & 4.3 & 8.0 \\
\hline 50 to 54 & 1.3 & 1.8 & 1.8 & 2.3 & 4.3 \\
\hline Men and women (age 50 to 54) & - & 7.4 & 9.7 & 13.2 & 17.9 \\
\hline \multicolumn{6}{|l|}{ Men only (age 50 to 54 ) } \\
\hline High school graduates & - & 11.4 & 11.5 & 17.6 & 19.1 \\
\hline University graduates & - & 28.7 & 37.0 & 38.4 & 41.3 \\
\hline Firm size 10 to 99 & - & 2.7 & 4.2 & 4.5 & 6.6 \\
\hline Firm size 100 to 999 & - & 7.1 & 11.2 & 16.5 & 21.6 \\
\hline Firm size $\geq 1000$ & - & 20.8 & 24.3 & 31.0 & 40.5 \\
\hline $\begin{array}{l}\text { University graduates in firm } \\
\text { size } \geq 1000\end{array}$ & 34.1 & 41.4 & 49.5 & 50.8 & 55.2 \\
\hline
\end{tabular}


Table 3 Lifetime employment among executives

\begin{tabular}{|c|c|c|c|c|c|c|}
\hline & \multicolumn{3}{|c|}{1993} & \multicolumn{3}{|c|}{1997} \\
\hline & $\begin{array}{c}\text { Lifetime } \\
\text { workers } \\
(\%)\end{array}$ & $\begin{array}{l}\text { Mean } \\
\text { tenure } \\
\text { (years) }\end{array}$ & $\begin{array}{c}\text { Internal } \\
\text { experience } \\
(\%) \\
\end{array}$ & $\begin{array}{c}\text { Lifetime } \\
\text { workers } \\
(\%)\end{array}$ & $\begin{array}{l}\text { Mean } \\
\text { tenure } \\
\text { (years) }\end{array}$ & $\begin{array}{c}\text { Internal } \\
\text { experience } \\
(\%) \\
\end{array}$ \\
\hline Average & 63.1 & 27.2 & 79.6 & - & - & - \\
\hline Chairman + Vice-chairman & 41.9 & 31.5 & 73.4 & - & - & - \\
\hline President & 32.1 & 22.4 & 57.4 & 34.7 & 24.4 & 64.1 \\
\hline Vice-president & 59.8 & 30.7 & 78.4 & - & - & - \\
\hline Managing directors & 64.6 & 27.0 & 80.5 & - & - & - \\
\hline \multicolumn{7}{|l|}{ By firm size (all executives) } \\
\hline Small firms $(<1000)$ & 49.3 & 24.2 & 71.6 & - & - & - \\
\hline Large firms $(\geq 1000)$ & 68.6 & 28.4 & 82.9 & - & - & - \\
\hline \multicolumn{7}{|l|}{ By firm size (presidents only) } \\
\hline Small firms $(<1000)$ & 22.2 & 19.1 & 50.9 & 24.8 & 21.9 & 58.1 \\
\hline Large firms $(\geq 1000)$ & 42.3 & 25.8 & 64.1 & 46.4 & 27.3 & 71.1 \\
\hline Top 100 firms & \multicolumn{3}{|c|}{ (all executives) } & \multicolumn{3}{|c|}{ (presidents only) } \\
\hline By firm size ${ }^{a}$ & 78.2 & 31.1 & 90.5 & 72.4 & 34.1 & 88.0 \\
\hline By capital & 84.5 & 30.6 & 91.2 & 80.2 & 35.7 & 90.0 \\
\hline
\end{tabular}


Table 4 Cox proportional hazard models predicting first job separation

\begin{tabular}{|c|c|c|c|c|c|c|}
\hline & \multicolumn{3}{|c|}{ (1) } & \multicolumn{3}{|c|}{ (2) } \\
\hline & Hazard ratios & & S.E. & Hazard ratios & & S.E. \\
\hline University graduate & -0.276 & $* *$ & $(0.090)$ & -0.261 & $* *$ & $(0.090)$ \\
\hline \multicolumn{7}{|l|}{ Firm size } \\
\hline 100 to 999 & -0.165 & $*$ & $(0.066)$ & -0.165 & $*$ & $(0.066)$ \\
\hline$\geq 1000$ & -0.374 & $* *$ & $(0.069)$ & -0.362 & $* *$ & $(0.069)$ \\
\hline Government & -1.047 & $* *$ & $(0.119)$ & -1.036 & $* *$ & $(0.119)$ \\
\hline Part-time & 0.251 & * & $(0.101)$ & 0.244 & * & $(0.101)$ \\
\hline Female & 0.606 & $* *$ & $(0.060)$ & 0.131 & & $(0.162)$ \\
\hline Married & 0.035 & & $(0.094)$ & -0.238 & $*$ & $(0.122)$ \\
\hline Female*married & & & & 0.547 & $* *$ & $(0.172)$ \\
\hline \multicolumn{7}{|l|}{ Cohort } \\
\hline LF entry 1955 to 64 & 0.082 & & $(0.091)$ & 0.072 & & $(0.091)$ \\
\hline LF entry 1965 to 74 & 0.058 & & $(0.089)$ & 0.038 & & $(0.090)$ \\
\hline LF entry 1975 to 84 & 0.080 & & $(0.096)$ & 0.056 & & $(0.096)$ \\
\hline LF entry 1985 to 94 & 0.189 & & $(0.115)$ & 0.180 & & $(0.115)$ \\
\hline Model $\chi^{2}$ & 342.16 & & & 352.36 & & \\
\hline$D f$ & 11 & & & 12 & & \\
\hline $\mathrm{N}$ & 1,983 & & & 1,983 & & \\
\hline
\end{tabular}


Table 5 Survival probability estimations

\begin{tabular}{|c|c|c|c|}
\hline & 10 years & 20 years & 30 years \\
\hline Total & 0.32 & 0.24 & 0.20 \\
\hline Men & 0.49 & 0.38 & 0.34 \\
\hline Women & 0.17 & 0.10 & 0.07 \\
\hline Less than university & 0.28 & 0.19 & 0.16 \\
\hline University & 0.54 & 0.49 & 0.43 \\
\hline \multicolumn{4}{|l|}{ Firm size } \\
\hline$<100$ & 0.22 & 0.13 & 0.10 \\
\hline 100 to 999 & 0.28 & 0.18 & 0.17 \\
\hline$\geq 1000$ & 0.40 & 0.32 & 0.26 \\
\hline Government & 0.67 & 0.58 & 0.51 \\
\hline \multicolumn{4}{|l|}{ Men only } \\
\hline Less than university & 0.44 & 0.32 & 0.28 \\
\hline University & 0.61 & 0.55 & 0.49 \\
\hline Firm size $\geq 1000$ & 0.63 & 0.57 & 0.49 \\
\hline Government & 0.77 & 0.72 & 0.65 \\
\hline
\end{tabular}


Table 6 Tenure distribution by gender and firm size (2000, percentages)

\begin{tabular}{|c|c|c|c|c|c|}
\hline & & Total & Men & Women & Men/Women \\
\hline \multirow[t]{4}{*}{ Tenure (years) } & All firms & 12.0 & 13.3 & 8.0 & 1.66 \\
\hline & 10 to 99 & 9.9 & 10.7 & 8.3 & 1.29 \\
\hline & 100 to 999 & 11.4 & 12.7 & 8.4 & 1.51 \\
\hline & $\geq 1000$ & 15.2 & 16.8 & 10.1 & 1.66 \\
\hline \multirow[t]{4}{*}{ Less than 1 year } & All firms & 7.3 & 6.2 & 9.9 & 0.62 \\
\hline & 10 to 99 & 9.7 & 8.9 & 11.5 & 0.77 \\
\hline & 100 to 999 & 7.0 & 6.0 & 9.2 & 0.65 \\
\hline & $\geq 1000$ & 4.7 & 3.3 & 8.8 & 0.38 \\
\hline \multirow[t]{4}{*}{10 years and over } & All firms & 45.5 & 51.0 & 32.7 & 1.56 \\
\hline & 10 to 99 & 37.5 & 40.6 & 30.8 & 1.32 \\
\hline & 100 to 999 & 43.3 & 49.1 & 30.8 & 1.59 \\
\hline & $\geq 1000$ & 58.1 & 64.5 & 38.5 & 1.67 \\
\hline \multirow[t]{4}{*}{20 years and over } & All firms & 21.5 & 25.9 & 11.0 & 2.35 \\
\hline & 10 to 99 & 15.2 & 17.6 & 9.9 & 1.77 \\
\hline & 100 to 999 & 19.3 & 23.8 & 9.6 & 2.47 \\
\hline & $\geq 1000$ & 31.9 & 37.5 & 14.9 & 2.51 \\
\hline \multicolumn{6}{|l|}{ (Age 35 and over) } \\
\hline \multirow[t]{4}{*}{20 years and over } & All firms & 36.5 & 41.3 & 22.2 & 1.86 \\
\hline & 10 to 99 & 24.3 & 27.2 & 17.3 & 1.57 \\
\hline & 100 to 999 & 34.3 & 39.4 & 20.2 & 1.95 \\
\hline & $\geq 1000$ & 55.0 & 59.0 & 36.4 & 1.62 \\
\hline
\end{tabular}

[SOURCE: Author's estimations using Wage Census] 
Table 7 Tenure distribution in selected countries (1998)

\begin{tabular}{lrrrrrrr}
\hline & $\begin{array}{c}\text { Average } \\
\text { (years) }\end{array}$ & \multicolumn{1}{c}{$\begin{array}{c}\text { Men } \\
\text { (years) }\end{array}$} & $\begin{array}{c}\text { Women } \\
\text { (years) }\end{array}$ & $\begin{array}{c}\text { Men/Women } \\
\text { ratio }\end{array}$ & $\begin{array}{c}<1 \text { year }^{\text {a }} \\
(\%)\end{array}$ & $\begin{array}{c}\text { 10 years } \\
(\%)\end{array}$ & $\begin{array}{c}2^{20} \text { years }^{\text {a }} \\
(\%)\end{array}$ \\
\cline { 2 - 8 } Japan & 11.6 & 13.1 & 8.2 & 1.60 & 7.6 & 43.2 & 21.4 \\
Belgium & 11.6 & 12.2 & 10.8 & 1.13 & 11.6 & 46.5 & 19.4 \\
Denmark & 8.5 & 9.2 & 7.7 & 1.19 & 25.1 & 33.5 & 11.4 \\
Finland & 10.6 & 11.1 & 10.0 & 1.11 & 17.6 & 42.5 & 17.3 \\
France & 11.3 & 11.7 & 10.8 & 1.08 & 15.0 & 45.0 & 18.7 \\
Germany & 10.4 & 11.3 & 9.2 & 1.23 & 16.1 & 38.3 & 17.0 \\
Greece & 13.2 & 13.8 & 12.2 & 1.13 & 12.6 & 51.2 & 13.3 \\
Ireland & 10.1 & 11.6 & 7.7 & 1.51 & 17.8 & 37.7 & 11.9 \\
Italy & 12.1 & 12.7 & 11.0 & 1.15 & 8.5 & 49.2 & 19.5 \\
Luxembourg & 11.2 & 12.3 & 9.2 & 1.34 & 11.4 & 44.2 & 16.4 \\
Netherlands & 9.4 & 10.6 & 7.8 & 1.36 & 16.3 & 36.5 & 11.9 \\
Portugal & 11.6 & 11.2 & 12.1 & 0.93 & 13.4 & 43.1 & 20.8 \\
Spain & 10.0 & 10.9 & 8.5 & 1.28 & 35.0 & 39.8 & 16.5 \\
Sweden & 11.9 & 12.0 & 11.8 & 1.02 & 14.8 & 47.8 & 17.0 \\
U.K. & 8.2 & 9.2 & 7.1 & 1.30 & 19.6 & 32.3 & 13.3 \\
U.S. & 6.6 & 7.1 & 6.1 & 1.16 & 26.0 & 25.8 & 9.0 \\
Average & 10.5 & 11.2 & 9.4 & 1.19 & 16.1 & 41.0 & 15.9 \\
\hline a & & & & & & &
\end{tabular}

1995 data.

[SOURCE: Auer and Cazes 2000; OECD 1997] 
Table 8 Retention rates in Japan and the U.S. (percentages)

\begin{tabular}{|c|c|c|c|c|c|c|c|}
\hline \multirow{2}{*}{ Age } & \multirow{2}{*}{ Tenure } & \multicolumn{2}{|c|}{ All } & \multicolumn{2}{|c|}{ Men } & \multicolumn{2}{|c|}{ Women } \\
\hline & & $1977-87$ & $1987-97$ & $1977-87$ & $1987-97$ & $1977-87$ & $1987-97$ \\
\hline \multicolumn{8}{|c|}{10 year retention rates (Japan) } \\
\hline 15 to 19 & Less than 5 & 32.9 & 31.2 & 54.2 & 45.5 & 14.4 & 17.0 \\
\hline \multirow[t]{2}{*}{20 to 24} & Less than 5 & 41.3 & 36.8 & 64.1 & 55.4 & 19.3 & 18.7 \\
\hline & $5+$ & 46.4 & 40.5 & 62.9 & 57.6 & 18.1 & 18.3 \\
\hline \multirow[t]{2}{*}{25 to 29} & Less than 5 & 55.0 & 50.4 & 65.4 & 64.2 & 35.4 & 28.1 \\
\hline & $5+$ & 68.0 & 60.5 & 73.6 & 69.9 & 48.1 & 40.2 \\
\hline \multirow[t]{2}{*}{30 to 34} & Less than 5 & 56.2 & 47.1 & 62.3 & 56.2 & 48.6 & 37.6 \\
\hline & $5+$ & 80.0 & 77.4 & 81.6 & 80.0 & 72.4 & 70.1 \\
\hline \multirow[t]{2}{*}{35 to 39} & Less than 5 & 57.9 & 45.7 & 58.6 & 54.3 & 57.3 & 40.7 \\
\hline & $5+$ & 83.4 & 81.5 & 86.2 & 84.1 & 73.4 & 73.4 \\
\hline \multirow[t]{2}{*}{40 to 44} & Less than 5 & 60.4 & 48.2 & 66.9 & 60.6 & 56.0 & 42.7 \\
\hline & $5+$ & 80.0 & 79.3 & 84.5 & 84.6 & 67.7 & 66.5 \\
\hline \multicolumn{8}{|c|}{15 year retention rates } \\
\hline \multicolumn{2}{|c|}{ Men only } & \multicolumn{2}{|c|}{ Japan } & \multicolumn{2}{|c|}{ U.S. } & & \\
\hline & & $1962-77^{\mathrm{a}}$ & $1982-97$ & $1963-78^{\mathrm{a}}$ & $1983-98$ & & \\
\hline 15 to 19 & Less than 5 & 36.4 & 40.0 & 5.6 & 4.6 & & \\
\hline \multirow[t]{2}{*}{20 to 24} & Less than 5 & 45.1 & 51.1 & 13.0 & 13.9 & & \\
\hline & $5+$ & 65.3 & 55.2 & 30.0 & 28.5 & & \\
\hline \multirow[t]{2}{*}{25 to 34} & Less than 5 & 42.7 & 52.2 & 22.2 & 20.1 & & \\
\hline & $5+$ & 73.0 & 73.6 & 47.3 & 48.1 & & \\
\hline \multirow[t]{2}{*}{35 to $39^{b}$} & Less than 5 & 37.7 & 46.7 & 24.4 & 22.1 & & \\
\hline & $5+$ & 75.9 & 78.4 & 54.5 & 52.1 & & \\
\hline
\end{tabular}

[SOURCE: Reprinted from Kato 2001]

${ }^{\text {a }}$ Reprinted from Hashimoto and Raisian 1985.

b 35 to 44 age category in the U.S. 
Table 9a Cumulative number of new jobs (male workers)

\begin{tabular}{|c|c|c|c|c|c|c|c|c|}
\hline & \multicolumn{4}{|c|}{ Accession rates $(\%)$} & \multicolumn{4}{|c|}{ Cumulative number of new jobs } \\
\hline & $1977^{\mathrm{a}}$ & 1991 & 1995 & 2003 & $1977^{\mathrm{a}}$ & 1991 & 1995 & 2003 \\
\hline 16 to 19 & 19 & 61.8 & 62.6 & 60.1 & 0.8 & 2.5 & 2.5 & 2.4 \\
\hline 20 to 24 & 26 & 31.6 & 29.0 & 32.1 & 2.1 & 4.1 & 4.0 & 4.0 \\
\hline 25 to 29 & 13 & 13.9 & 11.1 & 13.4 & 2.7 & 4.7 & 4.5 & 4.7 \\
\hline 30 to 34 & 8 & 10.9 & 7.5 & 10.2 & 3.1 & 5.3 & 4.9 & 5.2 \\
\hline 35 to 39 & 7 & 7.1 & 6.0 & 8.3 & 3.5 & 5.6 & 5.2 & 5.6 \\
\hline 40 to 54 & 5 & 6.8 & 6.0 & 6.8 & 4.2 & 6.7 & 6.1 & 6.6 \\
\hline 55 to 64 & 7 & 11.1 & 9.8 & 9.0 & 4.9 & 7.8 & 7.1 & 7.5 \\
\hline
\end{tabular}

[SOURCE: Author's estimations using Employment Trends Survey, various years]

${ }^{a}$ Reprinted from Hashimoto and Raisian (1985)

Table 9b Actual number of jobs held in Japan and the U.S.

\begin{tabular}{|c|c|c|c|c|c|c|}
\hline & \multicolumn{3}{|c|}{ Japan (1995) } & \multicolumn{3}{|c|}{ U.S. (1998) } \\
\hline & Total & Men & Women & Total & Men & Women \\
\hline \multicolumn{7}{|l|}{ Number of full-time jobs held } \\
\hline 20 to 24 & 1.3 & 1.4 & 1.2 & 2.6 & 2.2 & 3.1 \\
\hline 25 to 34 & 1.6 & 1.7 & 1.5 & 4.4 & 4.8 & 4.0 \\
\hline 35 to 44 & 1.9 & 1.9 & 1.8 & 5.1 & 5.8 & 4.5 \\
\hline 45 to 54 & 1.9 & 2.1 & 1.7 & 5.3 & 5.6 & 5.0 \\
\hline \multicolumn{7}{|c|}{$\begin{array}{l}\% \text { who have never changed jobs } \\
\text { (age group } 50 \text { to } 54 \text { only) }\end{array}$} \\
\hline Full-time jobs & 19.6 & 26.3 & 11.8 & 5.0 & 4.3 & 5.6 \\
\hline Full-time and part-time jobs & 21.7 & 26.3 & 16.5 & - & - & - \\
\hline
\end{tabular}


Table 10 Separation rates (percentages)

\begin{tabular}{|c|c|c|c|c|c|}
\hline & 1991 & 1994 & 1997 & 2000 & 2003 \\
\hline \multicolumn{6}{|l|}{ Separation rates } \\
\hline Total & 15.2 & 13.8 & 15.2 & 16.0 & 16.1 \\
\hline Men & 12.0 & 11.4 & 12.9 & 13.2 & 13.1 \\
\hline Women & 20.2 & 17.6 & 18.9 & 20.2 & 20.8 \\
\hline Regular workers & 13.8 & 12.3 & 13.6 & 13.5 & 13.3 \\
\hline Part-time workers & 24.7 & 23.9 & 25.2 & 27.6 & 27.8 \\
\hline Firm size $\geq 1000$ & 12.5 & 11.4 & 11.0 & 14.5 & 15.4 \\
\hline Firm size $\geq 1000$ (men only) & 8.0 & 7.4 & 7.4 & 10.3 & 10.3 \\
\hline \multicolumn{6}{|l|}{ Separation rates by reason for separation } \\
\hline \multicolumn{6}{|l|}{ Total } \\
\hline Expiration of contract & 8.2 & 8.4 & 10.7 & 10.5 & 10.5 \\
\hline Employer's discretion & 4.5 & 7.5 & 7.4 & 9.3 & 9.8 \\
\hline Transfers & $(1.8)$ & (3.1) & (3.1) & $(2.9)$ & (3.2) \\
\hline Mandatory retirement & 3.3 & 5.5 & 5.8 & 5.2 & 5.9 \\
\hline Personal reasons & 82.1 & 76.1 & 74.2 & 73.3 & 72.2 \\
\hline Marriage, childbearing and homecare & $(7.0)$ & $(7.8)$ & $(6.6)$ & $(5.3)$ & $(5.1)$ \\
\hline Death, illness & 2.1 & 2.6 & 1.8 & 1.7 & 1.8 \\
\hline \multicolumn{6}{|l|}{ Men } \\
\hline Expiration of contract & 10.3 & 9.4 & 13.1 & 10.6 & 11.1 \\
\hline Employer's discretion & 6.2 & 9.2 & 10.3 & 12.2 & 13.8 \\
\hline Transfers & (3.1) & $(5.0)$ & $(5.3)$ & $(5.1)$ & $(5.5)$ \\
\hline Mandatory retirement & 5.4 & 8.2 & 8.3 & 7.7 & 8.5 \\
\hline Personal reasons & 75.9 & 70.3 & 66.0 & 67.5 & 64.5 \\
\hline Marriage, childbearing and homecare & $(0.1)$ & $(0.2)$ & $(0.4)$ & $(0.3)$ & $(0.3)$ \\
\hline Death, illness & 2.3 & 2.9 & 2.4 & 2.0 & 2.1 \\
\hline \multicolumn{6}{|l|}{ Women } \\
\hline Expiration of contract & 6.1 & 7.5 & 8.0 & 10.5 & 9.9 \\
\hline Employer's discretion & 2.9 & 5.6 & 4.2 & 6.3 & 5.9 \\
\hline Transfers & $(0.5)$ & $(1.3)$ & $(0.6)$ & $(0.8)$ & $(0.9)$ \\
\hline Mandatory retirement & 1.3 & 2.7 & 3.0 & 2.7 & 3.3 \\
\hline Personal reasons & 87.9 & 81.9 & 83.6 & 79.2 & 79.5 \\
\hline Marriage, childbearing and homecare & $(13.5)$ & $(15.6)$ & $(13.7)$ & $(10.4)$ & (9.9) \\
\hline Death, illness & 1.9 & 2.3 & 1.2 & 1.3 & 1.5 \\
\hline
\end{tabular}

[SOURCE: Employment Trends Survey, MHLW, various years] 
Table 11 Accession rates

\begin{tabular}{|c|c|c|c|c|c|}
\hline & 1991 & 1994 & 1997 & 2000 & 2003 \\
\hline \multicolumn{6}{|l|}{ Accession rates } \\
\hline Total & 16.7 & 12.9 & 14.4 & 14.7 & 14.7 \\
\hline Men & 13.4 & 10.9 & 11.8 & 12.1 & 11.7 \\
\hline Women & 21.8 & 16.2 & 18.5 & 18.7 & 19.4 \\
\hline Regular workers & 14.8 & 11.7 & 12.4 & 11.8 & 11.5 \\
\hline Part-time workers & 34.5 & 27.1 & 32.4 & 38.8 & 34.3 \\
\hline Firm size $\geq 1000$ & 15.1 & 9.8 & 10.3 & 12.6 & 13.8 \\
\hline Firm size $\geq 1000$ (men only) & 10.2 & 6.6 & 6.8 & 8.5 & 8.8 \\
\hline \multicolumn{6}{|l|}{ Accession minus separation } \\
\hline Total & 1.5 & -0.9 & -0.8 & -1.3 & -1.4 \\
\hline Men & 1.4 & -0.5 & -1.1 & -1.1 & -1.4 \\
\hline Women & 1.6 & -1.4 & -0.4 & -1.5 & -1.4 \\
\hline Regular workers & 1.0 & -0.6 & -1.2 & -1.7 & -1.8 \\
\hline Part-time workers & 9.8 & 3.2 & 7.2 & 11.2 & 6.5 \\
\hline Firm size $\geq 1000$ & 2.6 & -1.6 & -0.7 & -1.9 & -1.6 \\
\hline Firm size $\geq 1000$ (men only) & 2.2 & -0.8 & -0.6 & -1.8 & -1.5 \\
\hline \multicolumn{6}{|c|}{ Accession rates for new university graduates } \\
\hline Firm size 5 to 99 & 9.2 & 18.2 & 25.6 & 28.0 & 27.1 \\
\hline Firm size 100 to 999 & 34.5 & 41.9 & 42.9 & 43.2 & 35.4 \\
\hline Firm size $\geq 1000$ & 52.5 & 37.7 & 28.7 & 25.7 & 32.5 \\
\hline Accession rates to Freeter status & a) & & & & \\
\hline New high school graduates & 13.1 & 22.1 & 25.1 & 35.4 & 38.6 \\
\hline New university graduates & 7.4 & 18.9 & 20.6 & 32.3 & 33.0 \\
\hline
\end{tabular}


Table 12 Changes in lifetime employment - Summary table

\begin{tabular}{|c|c|c|c|c|}
\hline & Years & Change & $\begin{array}{c}\text { Lifetime } \\
\text { employment }\end{array}$ & Source \\
\hline \multirow[t]{2}{*}{ Core workers } & 85 to 91 & $(-)$ & $(-)$ & MoL \\
\hline & 91 to 03 & $(-)$ & $(-)$ & MHLW; mine \\
\hline Standard employment & 95 to 03 & $(-)$ & $(-)$ & $\mathrm{MIC}$ \\
\hline Nonstandard employment & 95 to 03 & $(+)$ & $(-)$ & MIC \\
\hline Full-time & 91 to 01 & $(-)$ & $(-)$ & OECD (2003) \\
\hline Part-time & 91 to 01 & $(+)$ & $(-)$ & OECD (2003) \\
\hline \multicolumn{5}{|l|}{ Lifetime (native) workers } \\
\hline Men & 80 to 94 & $(+)$ & $(+)$ & Chuma (1997) \\
\hline Men & 80 to 90 & $(+)$ & $(+)$ & Tachibanaki (1984); mine \\
\hline Men & 90 to 00 & $(+)$ & $(+)$ & Mine \\
\hline Women & 80 to 90 & $(+)$ & $(+)$ & Tachibanaki (1984); mine \\
\hline Women & 90 to 00 & $(+)$ & $(+)$ & Mine \\
\hline Managers (men) & 80 to 90 & $(+)$ & $(+)$ & Ono (1997) \\
\hline Upper-level management & 75 to 84 & $(+)$ & $(+)$ & Ono (1997) \\
\hline Executives & 75 to 84 & $(+)$ & $(+)$ & Ono (1997) \\
\hline Executives & 93 to 04 & $(+)$ & $(+)$ & Wailerdsak \& Suehiro (2004); mine \\
\hline Survival rates ${ }^{\mathrm{a}}$ & 55 to 94 & no change & no change & Mine \\
\hline \multicolumn{5}{|l|}{ Tenure } \\
\hline Mean tenure & 80 to 03 & $(+)$ & $(+)$ & MHLW \\
\hline 10 years and over & 91 to 95 & no change & no change & OECD (1997) \\
\hline & 95 to 98 & $(+)$ & $(+)$ & Auer \& Cazes (2001) \\
\hline 20 years and over & 95 to 00 & no change & no change & OECD (1997); mine \\
\hline \multicolumn{5}{|l|}{ Retention rates } \\
\hline 10 year retention & 87 to 97 & no change & no change & Kato (2001) \\
\hline 15 year retention (men) & 77 to 97 & no change & no change & Hashimoto \& Raisian (1985); Kato (2001) \\
\hline \multicolumn{5}{|l|}{ Cumulative number of jobs } \\
\hline Men & 77 to 91 & $(+)$ & $(-)$ & Hashimoto \& Raisian (1985); mine \\
\hline Men & 91 to 03 & no change & no change & Mine \\
\hline \multicolumn{5}{|l|}{ Separation rates } \\
\hline Regular workers & 91 to 03 & no change & no change & MHLW \\
\hline Firm size $\geq 1000$ & 91 to 03 & $(+)$ & $(-)$ & MHLW \\
\hline Involuntary & 88 to 03 & $(+)$ & $(-)$ & MHLW, Rebick (2001); mine \\
\hline \multicolumn{5}{|l|}{ Accession rates } \\
\hline Regular workers & 91 to 03 & $(-)$ & $(-)$ & MHLW \\
\hline Firm size $\geq 1000$ & 91 to 03 & $(-)$ & $(-)$ & MHLW \\
\hline Into "freeter" status & 91 to 03 & $(+)$ & $(-)$ & MEXT \\
\hline \multicolumn{5}{|l|}{ Accession minus separation } \\
\hline Regular workers & 91 to 03 & $(-)$ & $(-)$ & MHLW \\
\hline Firm size $\geq 1000$ & 91 to 03 & $(-)$ & $(-)$ & MHLW \\
\hline
\end{tabular}

MoL: Ministry of Labor; MIC: Ministry of Internal Affairs and Communications; MHLW: Ministry of Health, Labor and Welfare; MEXT: Ministry of Education, Culture, Sports, Science and Technology.

${ }^{a}$ Compared to labor force entry cohort of 1946 to 1954. 

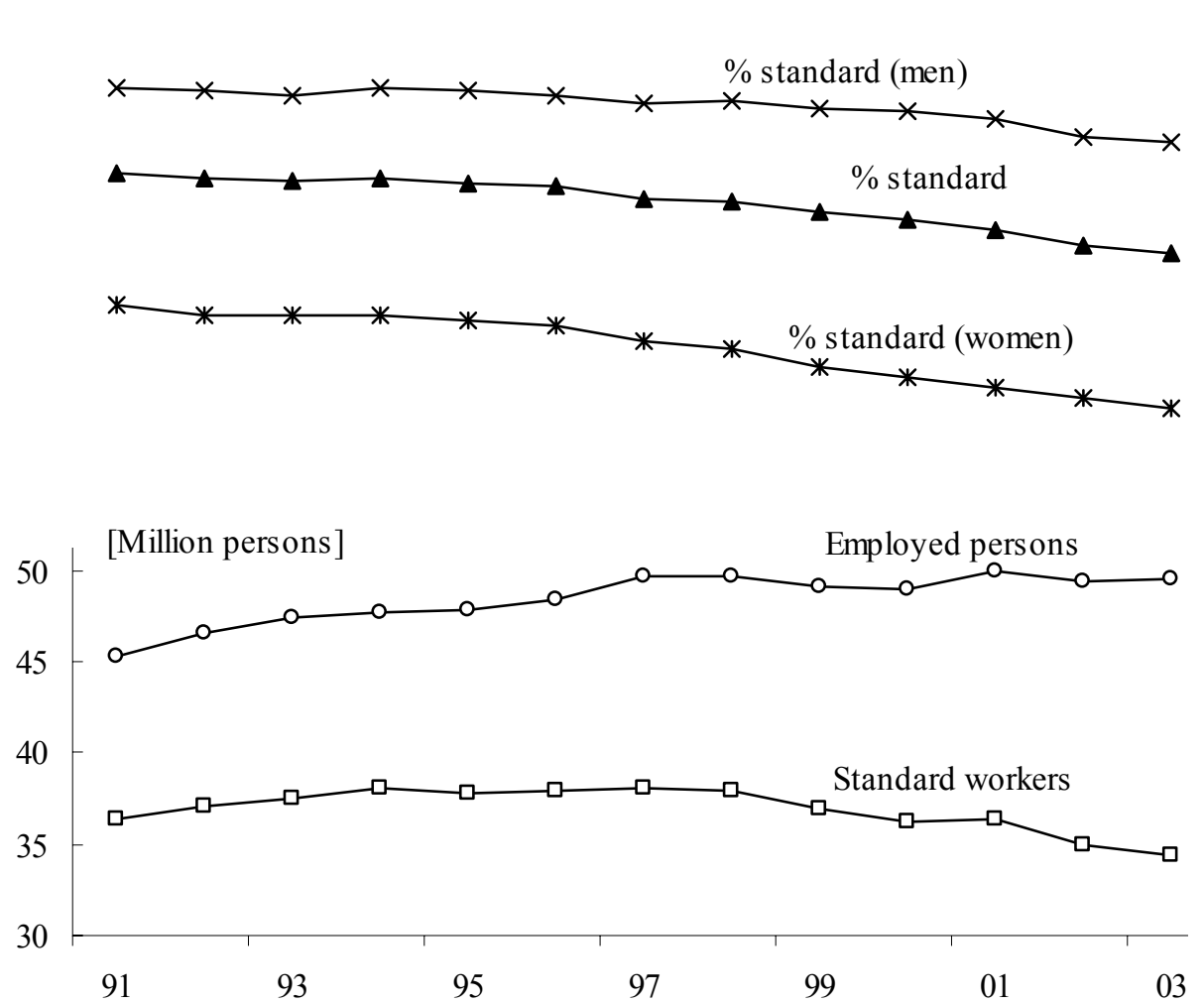

[SOURCE: Labor Force Survey, MIC]

Figure 1 Standard employment 

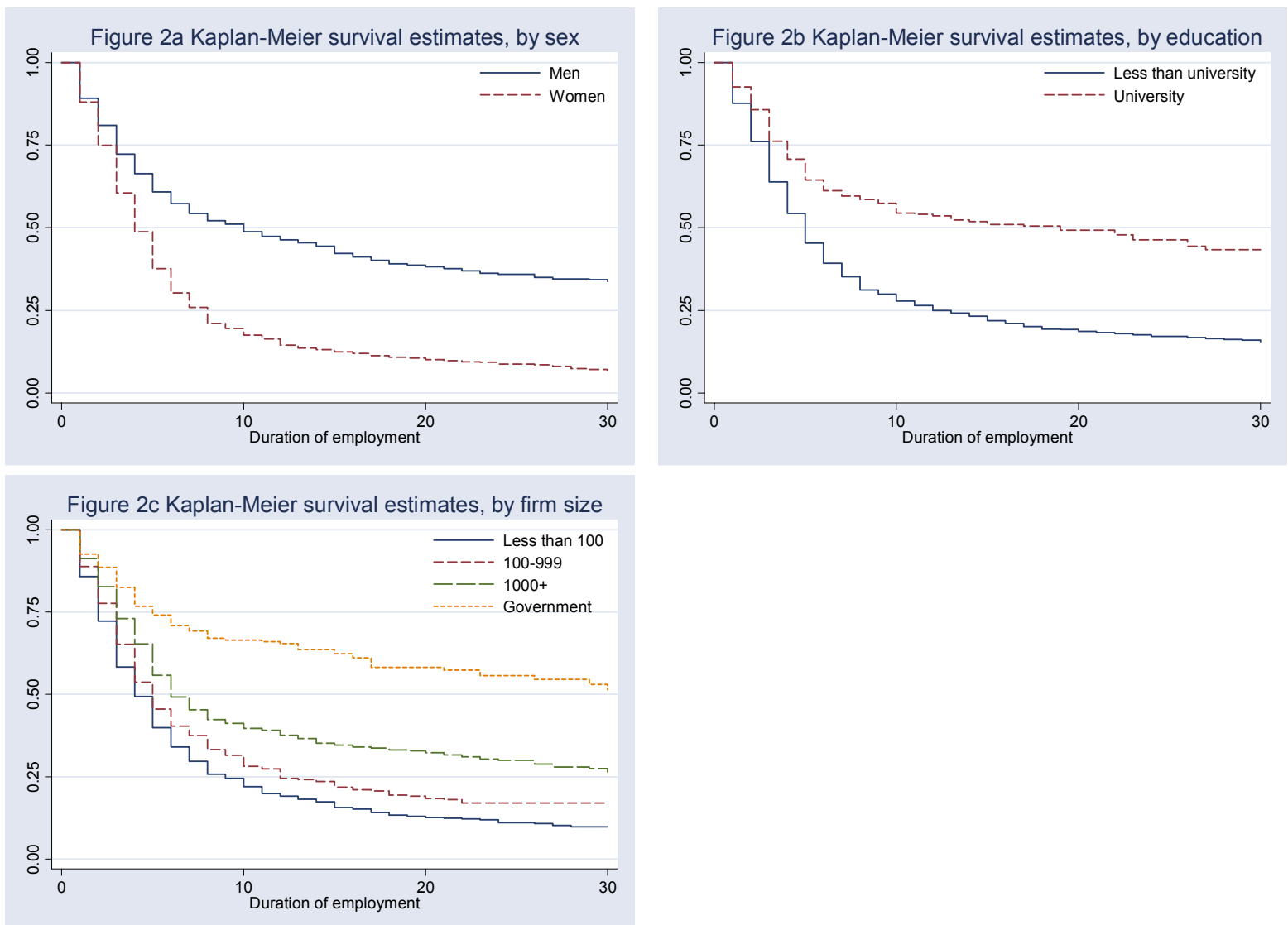


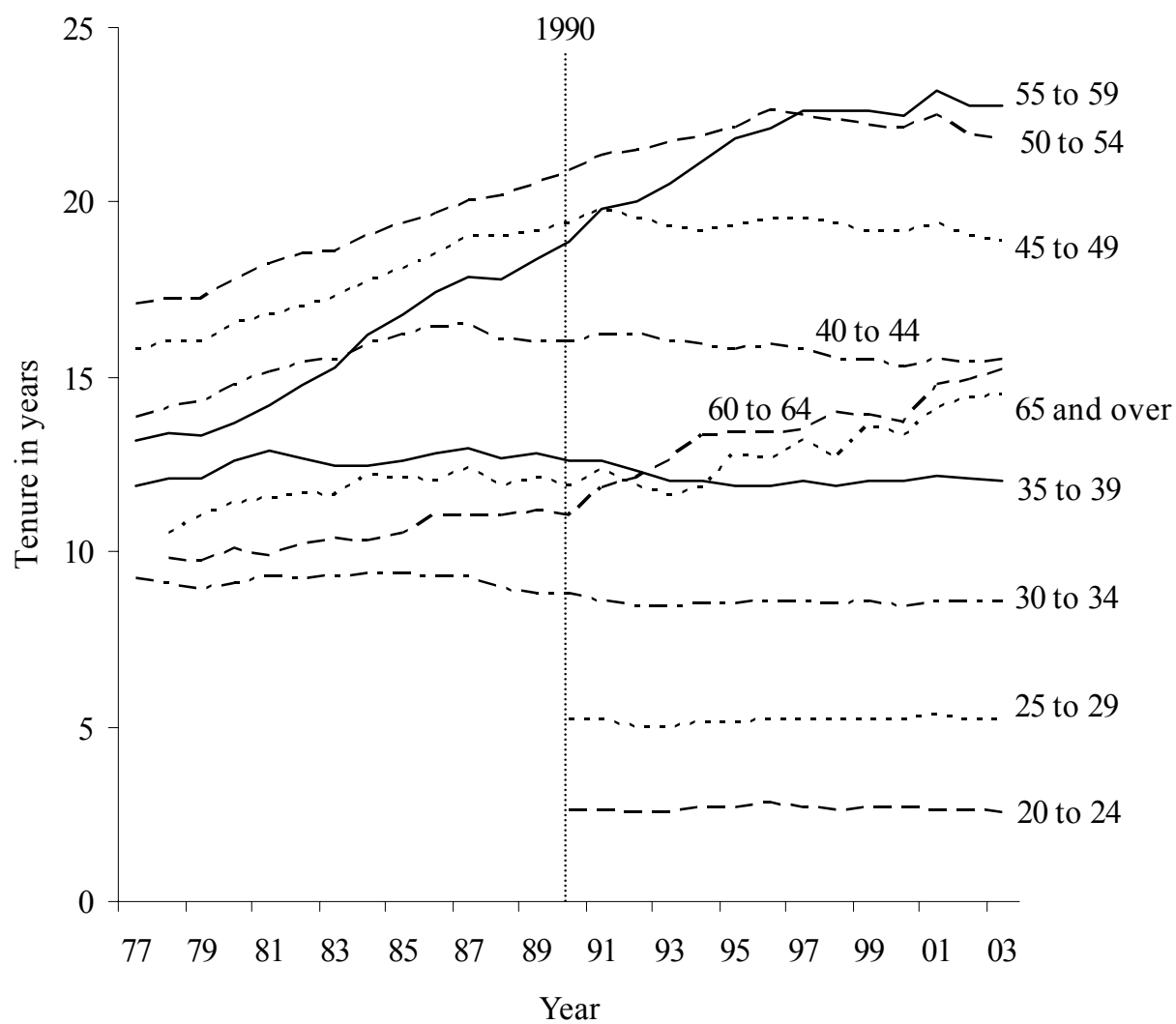

[SOURCE: Wage Census, MHLW, various years]

* Data for age groups less than 30 not available prior to 1990.

Figure 3 Tenure by age group for male employees 


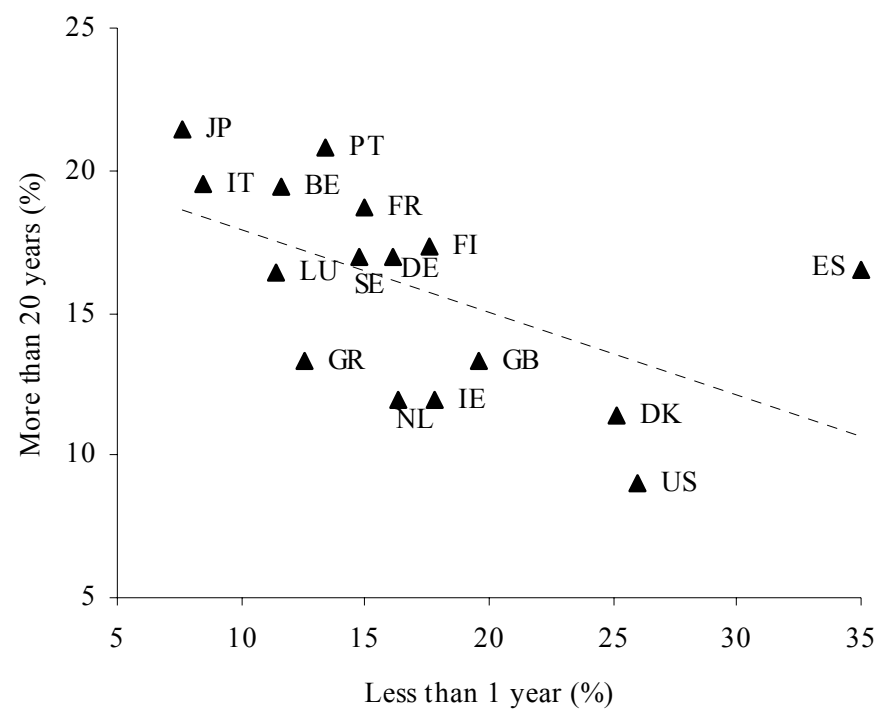

[SOURCE: OECD]

Figure 4 Distribution of employment by tenure categories (1995) 


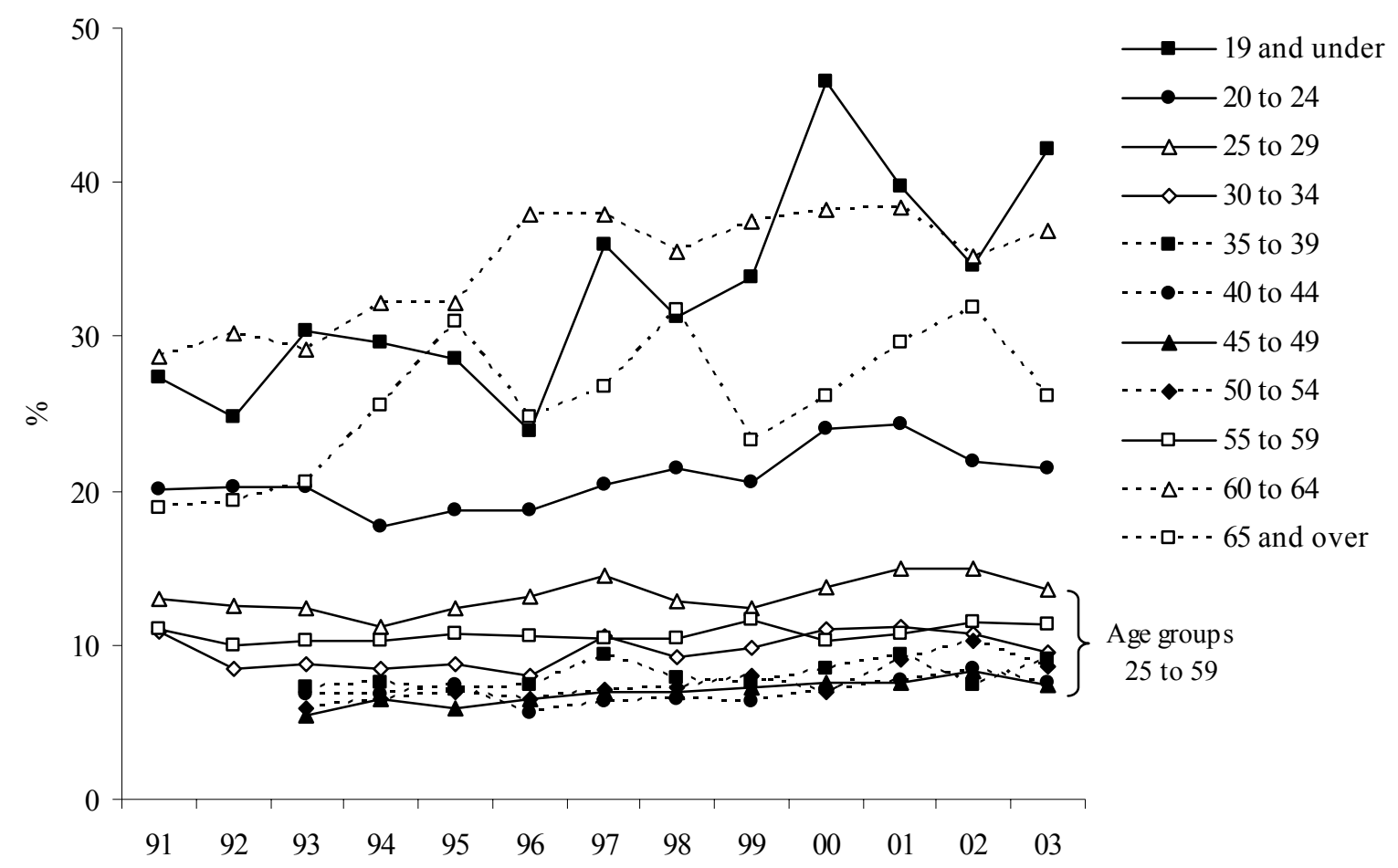

[SOURCE: Employment Trends Survey, MHLW]

Figure 5 Separation rates by age group (men only) 